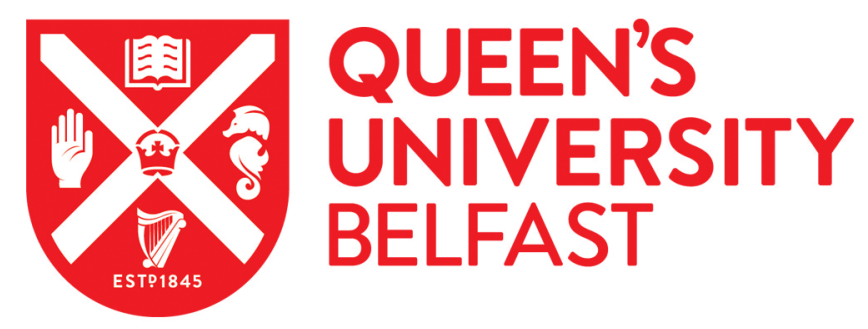

\title{
Vegetation changes and human settlement of Easter Island during the last millennia: a multiproxy study of the Lake Raraku sediments
}

Cañellas-Boltà , N., Rull, V., Sáez, A., Margalef, O., Bao, R., Pla-Rabes, S., Blaauw, M., Valero-Garcés , B., \& Giralt, S. (2013). Vegetation changes and human settlement of Easter Island during the last millennia: a multiproxy study of the Lake Raraku sediments. Quaternary Science Reviews, 72, 36-48.

https://doi.org/j.quascirev.2013.04.004

Published in:

Quaternary Science Reviews

Document Version:

Early version, also known as pre-print

Queen's University Belfast - Research Portal:

Link to publication record in Queen's University Belfast Research Portal

Publisher rights

Copyright 2013 The Author

\section{General rights}

Copyright for the publications made accessible via the Queen's University Belfast Research Portal is retained by the author(s) and / or other copyright owners and it is a condition of accessing these publications that users recognise and abide by the legal requirements associated with these rights.

Take down policy

The Research Portal is Queen's institutional repository that provides access to Queen's research output. Every effort has been made to ensure that content in the Research Portal does not infringe any person's rights, or applicable UK laws. If you discover content in the Research Portal that you believe breaches copyright or violates any law, please contact openaccess@qub.ac.uk. 


\section{Elsevier Editorial System(tm) for Quaternary Science Reviews Manuscript Draft}

Manuscript Number:

Title: Vegetation changes and human settlement of Easter Island during the last millennia: a multiproxy study of the Lake Raraku sediments.

Article Type: Research and Review Paper

Keywords: Easter Island; Paleoecology; Late Holocene; Human settlement; Deforestation; Verbena litoralis

Corresponding Author: Mrs. Núria Cañellas-Boltà, Phd student

Corresponding Author's Institution: Universitat de Barcelona

First Author: Núria Cañellas-Boltà, Phd student

Order of Authors: Núria Cañellas-Boltà, Phd student; Valentí Rull; Alberto Sáez; Olga Margalef; Roberto Bao; Sergi Pla-Rabes; Maarten Blaauw; Blas Valero-Garcés; Santiago Giralt

Abstract: Earlier palynological studies of lake sediments from Easter Island suggest that the island underwent a recent and abrupt replacement of palm-dominated forests by grasslands, interpreted as a deforestation by indigenous people. However, the available evidence is inconclusive due to the existence of extended hiatuses and ambiguous chronological frameworks in most of the sedimentary sequence studied. This has given rise to an ongoing debate about the timing and causes of the assumed ecological degradation and cultural breakdown. Our multiproxy study of a core recovered from Lake Raraku highlights the vegetation dynamics and environmental shifts in the catchment and its surroundings during the late Holocene. The sequence contains shorter hiatuses than in previously recovered cores and provides a more continuous history of environmental changes. The results show a long, gradual and stepped landscape shift from palm-dominated forests to grasslands. This change started c. $450 \mathrm{BC}$ and lasted about two thousand years. The presence of Verbena litoralis, a common weed, which is associated with human activities in the pollen record, the significant correlation between shifts in charcoal influx, and the dominant pollen types suggest human disturbance of the vegetation. Therefore, human settlement on the island occurred c. $450 \mathrm{BC}$, some 1500 years earlier than is assumed. Climate variability also exerted a major influence on environmental changes. Two sedimentary gaps in the record are interpreted as periods of droughts that could have prevented peat growth and favoured its erosion during the Medieval Climate Anomaly and the Little Ice Age, respectively. At c. AD 1200, the water table rose and the former Raraku mire turned into a shallow lake, suggesting higher precipitation/evaporation rates coeval with a cooler and wetter Pan-Pacific AD 1300 event. Pollen and diatom records show large vegetation changes due to human activities c. AD 1200. Other recent vegetation changes also due to human activities entail the introduction of taxa (e.g. Psidium guajava, Eucalyptus sp.) and the disappearance of indigenous plants such as Sophora toromiro during the two last centuries. Although the evidence is not conclusive, the American origin of Verbena litoralis re-opens the debate about the possible role of Amerindians in the human colonisation of Easter Island 
Dear Sir

Please find enclosed our manuscript entitled 'Vegetation changes and human settlement of Easter Island during the last millennia: a multiproxy study of Lake Raraku sediments' by Núria Cañellas-Boltà, Valentí Rull, Alberto Sáez, Olga Margalef, Roberto Bao, Sergi Pla-Rabes, Maarten Blaauw, Blas Valero-Garcés, Santiago Giralt to be considered for publication in Quaternary Science Reviews.

Easter Island is of considerable scientific interest and has been used as an illustrative example of human overexploitation of natural resources. However, its paleoecological history is poorly understood and continues to be controversial. This manuscript provides fresh evidence of vegetation shifts. It offers insights into the environmental changes that occurred on Easter Island and into the role of climate shifts and human activities during the last millennia. A multiproxy study of a sedimentary core recovered from Lake Raraku based on pollen, diatom and geochemical analyses was carried out. An agedepth model built from radiocarbon dates shows the presence of shorter hiatuses than in cores from earlier studies, which results in a more comprehensive and continuous record. In marked contrast to prevailing views, our results show a long and gradual landscape transformation with a stepped process of palm-forest decline and herb expansion. Pollen data suggest human disturbance some 1500 years earlier than is assumed.

The submission consists of this cover letter, the manuscript, eight figures, one table and one appendix. This paper consists of original, unpublished work that is not under consideration for publication elsewhere, in any form.

Yours faithfully,

\section{Núria Cañellas-Boltà}

Palynology \& Paleoecology Group Botanical Institute of Barcelona (IBB-CSIC-ICUB).

Passeig del Migdia s/n, 08038 Barcelona (Spain).

Phone: (+34) 932890611 //nuriacatcb@gmail.com / NCanellas@ibb.csic.es

and

Universitat de Barcelona - Facultat de Geologia. Dep. Estratigrafia, Paleontologia i G. Marines. Marti

Franques s/n 08028 Barcelona (Spain) 


\section{Highlights}

- We perform a multiproxy analysis of a sediment core from Lake Raraku (Easter Island)

- Shorter gaps than in earlier studies strengthen evidence on environmental changes

- Both climate and humans play a major role in ecological change in the last millennia

- Long, gradual and stepped palm-forest demise, and herb spread occurred from c. 450

$\mathrm{BC}$

- The expansion of the weed Verbena litoralis suggests early human colonisation 
Title:

Vegetation changes and human settlement of Easter Island during the last millennia: a multiproxy study of the Lake Raraku sediments.

Authors:

Núria Cañellas-Boltà ${ }^{1,2,}$, Valentí Rull ${ }^{1}$, Alberto Sáez ${ }^{2}$, Olga Margalef ${ }^{3}$, Roberto Bao ${ }^{4}$, Sergi PlaRabes $^{5,6}$, Maarten Blaauw ${ }^{7}$, Blas Valero-Garcés ${ }^{8}$, Santiago Giralt ${ }^{3}$

${ }^{1}$ Laboratory of Palynology and Paleocology, Botanic Institute of Barcelona (IBB-CSIC-ICUB), Palynology \& Paleoecology Group. Passeig del Migdia s/n, E-08038 Barcelona, Spain. Phone: (+34) 932890611 Fax: (+34) 932890614.

${ }^{2}$ Department of Stratigraphy, Paleontology and Marine Geosciences, Universitat de Barcelona, Spain. Marti Franques s/n E-08028 Barcelona, Spain. Phone (+34) 934034489 Fax (+34) 934021340

${ }^{3}$ Institute of Earth Sciences Jaume Almera (ICTJA-CSIC), Lluís Solé Sabarís s/n, E-08028 Barcelona, Spain.

${ }^{4}$ Faculty of Sciences, University of A Coruña, Campus da Zapateira s/n, 15071 A Coruña, Spain.

${ }^{5}$ Biogeodynamics and Biodiversity group, Center for Advanced Studies of Blanes (CEABCSIC), Cala St. Francesc 14, E-17300 Blanes, Spain.

${ }^{6}$ Centre for Ecological Research and Forestry Applications (CREAF), Cerdanyola del Vallès, E08193, Spain.

${ }^{7}$ School of Geography, Archaeology and Palaeoecology (GAP), Queen's University Belfast, Belfast BT7 1NN, UK.

${ }^{8}$ Pyrenean Institute of Ecology (IPE-CSIC). Apdo. 13034, E-50080 Zaragoza Spain. *correspondence to: nuriacatcb@gmail.com 


\section{ABSTRACT}

Earlier palynological studies of lake sediments from Easter Island suggest that the island underwent a recent and abrupt replacement of palm-dominated forests by grasslands, interpreted as a deforestation by indigenous people. However, the available evidence is inconclusive due to the existence of extended hiatuses and ambiguous chronological frameworks in most of the sedimentary sequence studied. This has given rise to an ongoing debate about the timing and causes of the assumed ecological degradation and cultural breakdown. Our multiproxy study of a core recovered from Lake Raraku highlights the vegetation dynamics and environmental shifts in the catchment and its surroundings during the late Holocene. The sequence contains shorter hiatuses than in previously recovered cores and provides a more continuous history of environmental changes. The results show a long, gradual and stepped landscape shift from palm-dominated forests to grasslands. This change started c. $450 \mathrm{BC}$ and lasted about two thousand years. The presence of Verbena litoralis, a common weed, which is associated with human activities in the pollen record, the significant correlation between shifts in charcoal influx, and the dominant pollen types suggest human disturbance of the vegetation. Therefore, human settlement on the island occurred c. $450 \mathrm{BC}$, some 1500 years earlier than is assumed. Climate variability also exerted a major influence on environmental changes. Two sedimentary gaps in the record are interpreted as periods of droughts that could have prevented peat growth and favoured its erosion during the Medieval Climate Anomaly and the Little Ice Age, respectively. At c. AD 1200, the water table rose and the former Raraku mire turned into a shallow lake, suggesting higher precipitation/evaporation rates coeval with a cooler and wetter Pan-Pacific AD 1300 event. Pollen and diatom records show large vegetation changes due to human activities c. AD 1200. Other recent vegetation changes also due to human activities entail the introduction of taxa (e.g. Psidium guajava, Eucalyptus sp.) and the disappearance of indigenous plants such as Sophora toromiro during the two last centuries. Although the evidence is not conclusive, the American origin of Verbena litoralis re-opens the debate about the possible role of Amerindians in the human colonisation of Easter Island.

Keywords: Easter Island, Paleoecology, late Holocene, Human settlement, Deforestation, Verbena litoralis 


\section{INTRODUCTION}

Easter Island is a tiny and remote island in the South Pacific Ocean (Fig. 1). The island has achieved global fame as the home of an ancient and complex society that erected megalithic statues, known as moai, and as an example of dramatic environmental degradation wrought by humans. This latter view is largely based on the palynological studies of lake sediments which have been interpreted as palm-dominated forests that were recently and suddenly replaced by grasslands. This apparently abrupt landscape change has been attributed to deforestation by the indigenous population (Flenley and King, 1984, Flenley et al., 1991, Flenley and Bahn, 2003, Diamond, 2005, Mann et al., 2008, Mieth and Bork, 2010). As a consequence, Easter Island has traditionally been regarded as an illustrative example of how humans can destroy their own habitat and cause a societal breakdown (Flenley and Bahn, 2003, Diamond, 2005), and it is often used as a model for the possible consequences of the over-exploitation of natural resources. Nevertheless, the environmental history of the island is poorly understood, and controversies about the timing and causes of the assumed deforestation, its consequences, and the role of humans are still ongoing (Mann et al., 2008, Rull et al., 2010).

According to the prevailing view of the history of Easter Island, a small group of Polynesian settlers reached the island from the west, most likely from the Marquesas, Tuamotu, Gambier or Austral Islands (Stefan, 2001, Flenley and Bahn, 2003) around AD 800-1000 (MartinssonWallin and Crockford, 2002, Vargas et al., 2006) (Fig. 1). As the islanders grew in number, the need for open spaces for agriculture and dwellings as well as the demand for firewood and timber would have increased rapidly. This would have led to rapid deforestation and soil degradation, thereby initiating a positive feedback of catastrophic consequences. According to this view, before the arrival of Europeans in the $18^{\text {th }}$ century, the inhabitants had completely deforested the island, which would have led to wars, famine and, finally, to cultural collapse (Flenley et al., 1991, Flenley and Bahn, 2003, Diamond, 2005).

Nevertheless this proposed sequence of historical events is not shared by all scholars. The settlement date is controversial and different chronologies ranging from AD 100 to AD 12001290 have been suggested (e.g. Heyerdahl and Ferdon, 1961, Hunt and Lipo, 2006, Butler and Flenley, 2010, Wilmshurst et al., 2011). Moreover, dating uncertainties have complicated the assignment of the precise age of the alleged deforestation, and its causal relationship with human activities has not been wholly accepted. Other additional or alternative causes for the vegetation clearance, such as climatic changes (McCall, 1993, Hunter-Anderson, 1998, Nunn, 2000) or the action of introduced fruit-eating rats preventing palm regeneration (Hunt, 2007, Hunt and Lipo, 2009) have also been proposed. Even the scenario of a completely forested 
island remains to be demonstrated (Rull et al., 2010). Likewise, the link between deforestation and cultural collapse has not been proved conclusively. Climate changes (Nunn, 2000, Stenseth and Voje, 2009), the European contact (Rainbird, 2002, Hunt and Lipo, 2009), a possible contact with the Amerindians (Dumont et al., 1998) or the isolation itself (van Tilburg, 1994) are also regarded as potential drivers of the cultural demise.

One of the main reasons for the ongoing debate about the ecological history of the island is the occurrence of extended hiatuses in most of the sedimentary sequences studied to date, which prevents us from understanding the events that occurred during the time when the great vegetation change took place (Flenley and King, 1984, Flenley et al., 1991, Dumont et al., 1998, Mann et al., 2008, Sáez et al., 2009, Rull et al., 2010).

Here we present the results of a multi-proxy study (sedimentology, geochemistry, diatoms, charcoal and pollen) of a radiocarbon-dated core recovered from Lake Raraku that seek to account for the tempo and mode of the vegetation changes in the last millennia, and to provide insights into how and when climate and/or human activities caused the paleoecological changes. The sedimentary record studied here has the advantage of having much shorter hiatuses than the cores analysed to date, thus providing a more complete palaeoecological sequence including new evidence from the period previously masked by sedimentary gaps. In addition, the identification of Verbena litoralis, a new pollen type observed within the island's sediments provides new and important information about potential causes.

\section{Regional setting}

Easter Island, which is a tiny $\left(164 \mathrm{~km}^{2}\right)$ volcanic island located in the South Pacific Ocean $\left(27^{\circ}\right.$ $07^{\prime} 16^{\prime}$ 'S, $109^{\circ} 21^{\prime}$ 59' $\mathrm{W}$ ), constitutes the easternmost Polynesian island (figure 1). It is one of the remotest places on Earth, about $3600 \mathrm{~km}$ from the Chilean coast and $2030 \mathrm{~km}$ from the nearest inhabited island (Pitcairn). The island has a triangular shape resulting from lava flows from three main volcanoes located at each of the three corners, and around 70 satellite cones. The Terevaka volcano $(511 \mathrm{~m})$ is the highest peak on the island. Hydrologically, the island is characterized by the absence of permanent surface streams due to the high permeability of the volcanic rocks (Herrera and Custodio, 2008). Two lakes (Rano Raraku and Rano Kau) and a fen (Rano Aroi) are the only permanent areas of surface freshwater. The climate is subtropical, with an average annual temperature of $21^{\circ} \mathrm{C}$ and a range of average monthly temperatures between $18^{\circ} \mathrm{C}$ in August and $24^{\circ} \mathrm{C}$ in January (Mann et al., 2008). The total annual precipitation is highly variable, ranging between 500 and $2000 \mathrm{~mm}$, with long alternating dry and humid periods (Horrocks and Wozniak, 2008). The current flora contains more than 200 vascular plants (Flenley, 1993), most of which $(\sim 85 \%)$ have been recently introduced (Flenley et al., 1991, 
Zizka, 1991, Flenley, 1993). Today the island is almost entirely covered by grassland (90\%), with some forests, shrublands and urban pioneer vegetation patches, mainly of introduced plants. Little is known about the native flora and fauna but they are described as very poor owing to the island's isolation and small area (Skottsberg, 1956, Zizka, 1991).

Raraku Lake is a small $\left(0.11 \mathrm{~km}^{2}\right)$, shallow $(\sim 3 \mathrm{~m})$, freshwater lake, situated at $75 \mathrm{~m}$ altitude a.s.l., inside a volcanic crater older than 300,000 yr (Baker et al., 1974, Sáez et al. 2009). The lake has a flat-bottom morphology and the margins of the small watershed are relatively steep. It is hydrologically closed, disconnected from the island's main groundwater aquifers and fed solely by precipitation (Herrera and Custodio, 2008). The catchment area is about $0.35 \mathrm{~km}^{2}$ and it is composed of volcanic tuff rich in glass, feldspar, and ilmenite (González-Ferran et al., 2004). Lake waters are well mixed, acidic ( $\mathrm{pH}$ around 6.3), dilute (average conductivity is $640 \mathrm{mS} \mathrm{cm}^{-1}$, Geller, 1992) and of $\mathrm{Cl}-\mathrm{HCO}_{3}-\mathrm{Na}$ type (Sáez et al. 2009). A dense littoral belt, mainly of Scirpus californicus, currently surrounds the lake and forms some floating mat patches.

\section{Methods.}

A multiproxy analysis was carried out on the uppermost section of the core RAR-08 recovered from Lake Raraku using a UWITEC corer installed on a UWITEC platform raft (see Sáez et al., 2009 for coring details).

\subsection{Radiocarbon dating and age-depth model}

Twelve AMS radiocarbon dates (table 1) from the uppermost $41 \mathrm{~cm}$ of the core RAR 08 were used to construct the age-depth model. Samples were processed following the standard pollen protocol excluding acetolysis, alcohol dehydration and silicone oil storage. Dating was performed at Poznan Radiocarbon Laboratory (Poland) and Beta-Analytic (USA).

Radiocarbon dating of the lake Raraku sediments has been surrounded by controversy. Besides the discontinuity of the sedimentary record (hiatuses) observed in the Lake Raraku sequences, another difficulty in establishing a sound chronological framework is the frequent existence of many chronological inversions in the radiocarbon dates (Flenley and King, 1984, Flenley et al., 1991, Flenley, 1996, Butler et al., 2004, Horrocks et al., 2012), which has been attributed to different sedimentary processes (Butler et al., 2004, Mann et al., 2008). In order to improve the chronological framework of the sequence studied, an age-depth model was built with a Bayesian approach using the Bacon software (Blaauw and Christen, 2011). This approach was chosen since it allows the incorporation of previously known stratigraphic information (i.e. presence of one or more gaps or hiatuses) as well as constraints on accumulation rate and variability in model building, which is crucial for a realistic chronological interpretation. Earlier works 
carried out on the Lake Raraku sediments have demonstrated the presence of hiatuses in its sedimentary record (Flenley et al., 1991, Dumont et al., 1998, Mann et al., 2008, Sáez et al., 2009). In the core studied in the present work (RAR 08), two hiatuses were inferred at 19.5 and $10 \mathrm{~cm}$ depth, taking into consideration the raw radiocarbon dates, X-ray Fluorescence (XRF) core scanner images (not shown), and the lithological and sedimentological features of the core. See Appendix 1 for the detailed specification of settings used for the building of the age-depth model with Bacon.

\subsection{Multiproxy analysis}

Magnetic susceptibility and density were measured every centimetre using a GEOTEK ${ }^{\mathrm{TM}}$ Multisensor Core Logger and total nitrogen (TN), total carbon (TC) and $\delta^{13} \mathrm{C}$ were determined by a Finningan delta Plus EA-CF-IRMS spectrometer. Twenty-four samples were extracted from the upper $26 \mathrm{~cm}$ of the core and processed for pollen analysis according to slightly modified standard laboratory procedures (Rull et al., 2010b), which include sieving, $\mathrm{KOH}, \mathrm{HCl}$ and $\mathrm{HF}$ digestions, and acetolysis. Lycopodium tablets were added to each sample before chemical processing as an exotic marker. Microscopic slides were mounted in silicone oil and pollen counting was performed until at least 200 pollen grains had been reached, excluding aquatic and semi-aquatic taxa (Cyperaceae and Polygonum). Charcoal particles larger than $5 \mu \mathrm{m}$ of twentyfive randomly distributed fields at x20 magnification were counted, and the total concentration was inferred using the exotic markers (Lycopodium). The charcoal counts were carried out using the same pollen slides. The charcoal influx was calculated from total concentration, using accumulation rates and sediment density. Their values for the uppermost centimetres of the sequence were not calculated owing to the lack of suitable density measurements. Samples for diatom analysis were taken every $2.5 \mathrm{~cm}$ and were processed using standard techniques (Renberg, 1990). The cleaned subsamples were dried onto coverslips and mounted on microscope slides with Naphrax ${ }^{\circledR}$ high refractive medium (R. I. = 1.73). At least 400 valves were counted per sample. Diagrams for both pollen and diatom data were plotted with psimpoll 4.26 (Bennett, 2009). Statistically significant pollen and diatom zones were obtained with the same software, using the method of optimal splitting by information content (OSIC) (Bennett, 1996).

\section{Results and interpretation}

\subsection{Sedimentological, geochemical and chronostratigraphic data.}

According to the age-depth model (figure 2), the section of the core records the time spanning $1790 \mathrm{yr} \mathrm{BC}$ ( 2570 to $\sim 1270 \mathrm{BC}$ at $95 \%$ uncertainty intervals). The sequence is interrupted by two sedimentary hiatuses that span from c. AD 500 to c. AD 1165 and from c. AD 1570 to c.

AD 1720. 
This stratigraphic interval, which is $26 \mathrm{~cm}$ thick, is composed of diatom-bearing, peaty sediments. Two different facies were identified (figure 3). The lowest part of the core, below $19.5 \mathrm{~cm}$ depth, is composed of reddish-brown massive or banded muddy peat, formed mainly by macroremains of sedges. It has been interpreted as deposited in a mire environment (Sáez et al., 2009, Cañellas-Boltà et al., 2012). Above this depth, the sediments are composed of silicate-rich silty peat, interpreted as deposited in a shallow lake surrounded by floating mats as currently shown by the Raraku crater (Sáez et al., 2009, Cañellas-Boltà et al., 2012). See Sáez et al. (2009) for a more detailed lithostratigraphic description. According to the age model, the mire episode recorded in this short core comprises the last 2290 years (from c. 1790 BC until c. AD 500 ) of a long Holocene mire sedimentation phase initiated approximately 8900 years ago. The upper lacustrine episode covers the remaining $\sim 800$ years until the present (Sáez et al., 2009).

Slight changes in density, magnetic susceptibility (MS), C/N ratio, total carbon (TC), $\delta^{13} \mathrm{C}$ and total nitrogen (TN) are observed along the core (figure 3). After an initial increase of up to 24 $\mathrm{cm}, \mathrm{TC}$ and $\mathrm{C} / \mathrm{N}$ values tend to decrease up to $17 \mathrm{~cm}$ depth. In contrast, density, $\delta^{13} \mathrm{C}$, and TN remain fairly constant up to this depth. A large peak of magnetic susceptibility is observed at the bottom. From 17 to $10 \mathrm{~cm}$ depth, TC, TN, C/N,$\delta^{13} \mathrm{C}$ and MS values remain essentially constant except for a peak of magnetic susceptibility detected around $16 \mathrm{~cm}$ depth, which coincides with a decrease in TC, $\mathrm{C} / \mathrm{N}$ and density. From 10 to $6 \mathrm{~cm}$ depth, a marked decrease in sediment density, TC, TN and in $\delta^{13} \mathrm{C}$ is observed. The $\mathrm{C} / \mathrm{N}$ peak at $8 \mathrm{~cm}$ depth coincides with a TN fall. From $6 \mathrm{~cm}$ depth to the top, the values of the parameters remain constant with minor fluctuations.

\subsection{Pollen and charcoal data}

The pollen results (percentage) and charcoal data (influx) are depicted in Figure 4. The palynological record is characterised by the occurrence of few pollen types, with palm, grasses and Verbena litoralis Kunth as the predominant elements. Besides palms, Triumfetta semitriloba Jacquin, Sophora toromiro (Philippi) Skottsb., and Asteraceae are the other main woody taxa identified through the record. Several ferns, Cyperaceae, Polygonum acuminatum Kunth and cf. Solanum are also present in moderate to relatively high percentages. The main change identified is the replacement of the woody plant pollen (mainly palms) by herbaceous plant pollen (primarily Poaceae and Verbena litoralis). Two zones are statistically significant, highlighting this main shift around $18.5 \mathrm{~cm}$ depth. Some changes inside these zones allow us to distinguish different subzones (figure 4). 


\subsubsection{Pollen zone RAP-1 (26-18.5 cm, c.1790 BC to c. AD 1200)}

This zone is characterised by a high dominance of tree and shrub pollen, particularly from palms, with smaller amounts of Triumfetta and Sophora. Fern spores show low abundances in this zone, as does Asteraceae pollen, which is absent from several samples. Two subzones can be identified. The subzone RAP-1a (26 to $22.5 \mathrm{~cm}$ depth; $1790 \mathrm{BC}$ - c. $450 \mathrm{BC}$ ) is clearly dominated by palm pollen, with values around $90 \%$ of the total pollen sum. Triumfetta, Sophora, and few Asteraceae complete the tree and shrub pollen record in this subzone. A few Cyperaceae and herb pollen are also observed. In the subzone RAP-1b (22.5 to $18.5 \mathrm{~cm}$ depth; c. $450 \mathrm{BC}$ - c. AD 1200), palm pollen declines markedly, with percentage values reaching only up $60-70 \%$ of the pollen sum. Poaceae, Verbena litoralis and Cyperaceae pollen percentages show a marked increase. Solanum and psilate monoletes undergo a slight increase and psilate triletes appear in the record for the first time. Triumfetta and Sophora are still present and charcoal influx shows a slight increase. Asteraceae are absent.

\subsubsection{Pollen zone RAP-2 (18.5 cm depth to top) (c. AD 1200- to present)}

Palm pollen undergoes a second significant drop at $18.5 \mathrm{~cm}$ and herb pollen becomes dominant, with alternating dominance of Poaceae and Verbena litoralis. Ferns spores (primarily psilate monoletes) and Asteraceae pollen are also more abundant in this zone than in RAP-1. The considerable increase in charcoal influx throughout this zone is also noteworthy. Three subzones can be distinguished according to changes in the record of palms, herbs and charcoal. The subzone RAP-2a (from 18.5 to $12.5 \mathrm{~cm}$ depth; c. AD 1200- c. AD 1475) is characterized by co-dominance of Verbena and Poaceae, intermediate abundances of palm pollen (20-37\%), and high abundances of Cyperaceae. Charcoal influx is remarkably higher than in the previous zone. In the subzone RAP-2b (from 12.5 to $6.5 \mathrm{~cm}$; c. AD 1475- c. AD 1875), palm pollen falls and shows the lowest percentages in the record $(<10 \%)$, Poaceae shows a slight decrease and Verbena litoralis becomes dominant. Other distinctive features of this subzone are the decrease in Cyperaceae and the highest charcoal influx values. The uppermost section of the core (the subzone RAP-2c, $6.5 \mathrm{~cm}$ depth to the top; from c. 1875 to present) is characterised by a marked increase in Poaceae, which become dominant at the expense of Verbena. New pollen taxa appear in the record such as Psidium guajava L., Plantago sp. and Eucalyptus sp.. The absence of Sophora and the slight increase in palm pollen are also significant.

\subsection{Diatom data}

Pseudostaurosira trainorii E.A. Morales, Pseudostaurosira neoelliptica (Witkowski) E.A. Morales and Pinnularia joculata (Manguin) K. Krammer are the most abundant diatoms in the record (figure 5). The main shift is the replacement of benthic by tychoplanktonic taxa around 
$19.5 \mathrm{~cm}$ depth, which marks the boundary between two statistically significant zones. This boundary roughly coincides with the boundary between the previous pollen zones.

\subsubsection{Diatom zone RAD-1 (26-19.5 cm depth) (c. 1790 BC - c. AD 500)}

This zone is dominated by benthic diatoms, notably Pinnularia joculata. The presence of numerous aerophilic benthic taxa (e.g. Eolimna minima (Grunow) H. Lange-Bertalot, Hantzschia amphioxys (Ehrenberg) Grunow, Luticola sp. aff. mutica (Kützing) Mann, Nitzchia debilis (Arnott) Grunow, Pinnularia sp. aff. divergentissima) is also noteworthy. Above 22.5 $\mathrm{cm}$ (c. $450 \mathrm{BC}$ ) slight changes in the diatom assemblages are observed, with an increase in non aerophilous $P$. joculata up to values of $80 \%$ of the total assemblage. Most of the diatoms in this zone have an acidophilic character. The diatom frustules/chrysophycean stomatocysts ratio shows low values.

\subsubsection{Diatom zone RAD-2 (19.5 depth to top) (c. AD 1165 - to the present)}

This zone is characterised by the predominance of tychoplanktonic and alkaliphilic diatoms belonging to the Fragilaria s. 1. group, basically Pseudostaurosira neoelliptica and P. trainorii, which replace the benthic diatoms of the former zone. Furthermore, two subzones can be differentiated. The subzone RAD-2a (19.5 to $10 \mathrm{~cm}$ depth, c. AD 1165- c. AD 1570) is dominated by Pseudostaurosira neoelliptica and P. trainorii (absent in the previous zone), and displays a diverse assemblage of benthic diatoms, with $P$. joculata as the most abundant one but with lower values than in RAD-1. By contrast, the subzone RAD-2b $(10 \mathrm{~cm}$ depth to the top, $\mathrm{c}$. AD 1570- to the present) is almost entirely dominated by tychoplanktonic diatoms, and benthic diatoms are practically absent with a minor presence of Pinnularia.

An overall upward increase in the frustules/chrysophycean stomatocysts ratio is observed in this zone. After an isolated peak around $16 \mathrm{~cm}$ depth, a gradual rising trend occurs from 14 to $4 \mathrm{~cm}$. This ratio shows a marked decrease in the four top centimetres.

\subsection{Vegetation and palaeoenvironment reconstruction}

The reconstruction of the environmental and vegetation dynamics in the Raraku catchment and surroundings through time is based on pollen and diatom zoning, taking into consideration changes in the sedimentary facies, the charcoal influx and the physical and geochemical proxies. Five main phases can be recognised (figure 6).

\subsubsection{Phase 1: c. 1790 to c. 450 BC}

Both the sedimentary composition (peaty deposits) and the diatom data suggest that the bottom of the Lake Raraku crater was covered by a mire during this period. As in earlier studies, the Lake Raraku pollen record provides evidence of a wooded landscape dominated mainly by palm 
trees in the Lake Raraku surroundings around the start of the late Holocene. Triumfetta semitriloba and Sophora toromiro shrubs would have dominated the understorey. High total carbon (TC around 40\%), $\mathrm{C} / \mathrm{N}$ values exceeding 10 and heavy $\delta^{13} \mathrm{C}$ values indicate the prevalence of terrestrial organic matter in the sediment, mainly derived from C3 plants (Meyers and Terranes, 2001). The predominance of benthic diatoms, many of which show an aerophilic affinity, points to a mire environment with ephemeral and shallow water ponds. Furthermore, the presence among the aerophilic taxa of subaerial species such as Hantzschia amphioxys, Luticola mutica, Nitzschia debilis and Pinnularia borealis Ehrenberg (figure 4) could indicate periods with higher aridity and drying out conditions (Denys, 1991, Johansen, 2010).

\subsubsection{Phase 2: c. 450 BC to c. $A D 1200$}

At the start of this period, the characteristics of the sediments point to the continuity of the mire conditions of Phase 1. However, the decrease in benthic diatoms with aerophilic affinity and the progressive diminution of the $\mathrm{C} / \mathrm{N}$ ratio during this phase suggest a peaty environment that gradually became waterlogged. This environment could have favoured the growth of semiaquatic plants such as Cyperaceae.

Sedimentary and chronological evidence indicate a period of subaerial exposure of the depositional surface after AD 500 and before AD 1200 and the subsequent erosion resulting in a hiatus in the sequence. This hiatus was probably the result of drought phases between AD 500 and AD 1200 (Mann et al., 2008, Sáez et al., 2009). The Raraku basin was flooded again c. AD 1200 , as evidenced by changes in the composition of the sediment, and by the onset of a trend towards tychoplanktonic dominance in diatom assemblages.

The first significant vegetation change in the sequence occurred c. 450 BC (790 BC - 90 BC) when a trend of replacement of wooded landscape by herb-dominant communities starts. In this regard, a marked increase in herbaceous taxa (notably grasses, Verbena litoralis and Solanum sp.) coupled with a fall in palm pollen indicates a reduction in the arboreal cover, and an openness of the landscape (figure 6). The expansion of herbs, especially the spread of $V$. litoralis, a weed/ruderal plant that is associated with human-disturbed sites (Zizka, 1991, Wagner et al., 1999), suggests the possible onset of human presence at the beginning of this phase. A slight increase in charcoal influx during this period, pointing to greater fire incidence, could also support human presence. The small rise in fern spores (mainly psilate monoletes) could be due to the increase in local burning. Secondary fern communities are rapidly established in areas affected by fire (Rull, 1999, McGlone and Wilmshurst, 1999).

\subsubsection{Phase 3: c. $A D 1200$ to c. $A D 1475$}

The sharp increase in tychoplanktonic diatoms and the compositional and geochemical data (lower values of TC, $\mathrm{C} / \mathrm{N}$ and $\delta^{13} \mathrm{C}$ ) demonstrate that the Raraku site was transformed into a 
shallow lake with abundant littoral vegetation not unlike conditions at present. Indeed $\mathrm{C} / \mathrm{N}$ and $\delta^{13} \mathrm{C}$ values strongly suggest that the organic matter is mainly terrestrial in origin. Geochemical data show a higher increase in sediment delivery to the lake (higher silicate content). The dominance of small diatoms of the Fragilaria (s.l) group, which includes the genus Pseudostaurosira, also corroborates the increased erosion in the catchment. Indeed, this group of diatoms is typical of shallow but open waters and littoral zones, and their growth is favoured by alkalinizing base cations released from the catchment (Reed et al., 1999, Axford et al., 2009). The dominance of these diatoms would indicate enhanced runoff and increased cation input to lake waters, probably as a result of vegetation clearance. The increase in the frustules/chrysophycean stomatocysts ratio could also point to enhanced eutrophication conditions (Smol, 1985).

A second notable vegetation shift took place c. AD 1200 and entailed a drastic landscape transformation. The pollen record was no longer dominated by palms but by herbaceous taxa, indicating the increasing prevalence of open herbaceous communities (Figure 6). Poaceae and Verbena litoralis continued their expansion initiated in the previous phase, but this time with a pronounced acceleration. Although the palm pollen decreased gradually during all this period, palms remained as an important element of the vegetation, together with Triumfetta, Sophora, and Asteraceae-tubiflorae, which increased in abundance during this phase. The large rise in charcoal influx suggests higher fire frequency, which is probably associated with continued human disturbance.

\subsubsection{Phase 4: c. $A D 1475$ to c. $A D 1875$}

The sedimentary, geochemical and diatom records indicate persistent shallow-lake conditions during this period. However, a sedimentary hiatus between c. AD 1570 to AD 1720 indicates other period of drought. During this phase the palm pollen attains its lowest values $(<10 \%)$, suggesting a landscape almost entirely dominated by herbaceous plants, with abundant Verbena, and a few sparse palms. A notable increase in Verbena percentage and charcoal influx values probably indicate the continued intensification of disturbance by humans.

\subsubsection{Phase 5: c. AD 1875 to present}

Significant changes in vegetation took place during this last phase. The Raraku landscape became dominated by Poaceae after a sharp fall in Verbena litoralis. However, Verbena continued to be an important element of the vegetation as shown by the marked pollen values still observed in the sediment. Another striking change is the presence of pollen of plants known to be introduced by humans during the $20^{\text {th }}$ century, such as Psidium guajava and Eucalyptus, showing an increase in allocthonous elements. The endemic shrub Sophora toromiro, which survives today only as a cultivated plant on the island and in botanical gardens in other parts of 
the world (Zizka, 1991), disappears from the Raraku area during this phase. The highest values of the frustules/chrysophycean stomatocysts ratio also suggest the maximum eutrophic conditions in this record.

Unfortunately, as stated in the Methods section (section 3), it was not possible to calculate charcoal influx in the uppermost centimetres of the sequence, which prevents the interpretation of fire dynamics in this period.

\section{Discussion}

The multiproxy study of a Lake Raraku sedimentary core provides relevant information about the late Holocene vegetation dynamics and environmental changes in the Lake Raraku catchment and surroundings. Despite the presence of two sedimentary hiatuses, the unrecovered time span in this study is considerably shorter (around 650 and $200 \mathrm{yr}$, respectively) than in earlier studies of the Lake Raraku sediments (around 3000-6000 yr in e.g. Flenley et al., 1991, Mann et al., 2008) (figure 6). Our record therefore provides a more comprehensive view of the late-Holocene history of the lake and furnishes empirical evidence for vegetation changes and their potential causes that have remained hidden to date.

\subsection{Climate changes}

Earlier studies of the island have suggested significant climatic changes during the Last Glacial Maximum and the early-mid Holocene (Flenley et al., 1991, Azizi and Flenley, 2008, Sáez et al., 2009) but there are very few data on more recent times. Our study shows that both climate and human activities have largely modified the landscape during the last millennia. Besides changes in the aquatic organisms and chemical proxies (section 4.4), the occurrence of sedimentary gaps in the record could be interpreted as a result of intensified erosion during dry climatic phases (Mann et al., 2008, Sáez et al., 2009). These dry phases would have resulted in a fall in the water level or in a total drying out, thus favouring peat erosion and/or preventing its growth. The older gap (c. AD 500 to c. AD 1200) is roughly coeval with the Medieval Climate Anomaly (ca $9^{\text {th }}-14^{\text {th }}$ centuries) when warm and dry conditions prevailed in the South Pacific Basin (Nunn and Briton, 2001, Nunn, 2007). After this dry period, the rise in the water level at Raraku led to the formation of a lake. This climate shift could be attributed to the AD 1300 event, a phase of rapid cooling and wetter conditions, especially in the eastern Pacific Basin, which has been linked to an increase in the frequency of El Niño events (Nunn 2000, 2007, Nunn and Briton, 2001). The younger hiatus ( AD 1570 to AD 1720) could be associated with the occurrence of several drought phases in the Pacific Basin during the Little Ice Age (Nunn, 2000, 2007). The continued dominance of tychoplanktonic diatoms and the sedimentary composition suggest higher lake levels and a 
prevailing wet climate from c. AD 1200. These climatic changes would have been coupled to human activities, resulting in synergistic effects that could have favoured or slowed down population growth, palm growing and regeneration, or fire incidence.

\subsection{Palm forest decline and recent vegetation changes}

Palynological evidence from Raraku sediments supports the occurrence of former palmdominated vegetation at the start of the late Holocene and the progressive grassland expansion that replaced these palm forests (figure 6). This significant change in vegetation, which started c. $450 \mathrm{BC}$, entailed a gradual and stepped replacement that lasted about two thousand years. Three main palm declines are identified in the record. The first decline took place c. $450 \mathrm{BC}$ although palms still remained as the dominant element in the landscape. At c. AD 1200, the second palm fall led to a more open landscape with the probable onset of dominant herbaceous communities. The last palm decrease occurred c. AD 1475, but palm pollen did not disappear entirely from the record as has been reported in other paleoecological studies (Dumont et al., 1998). This is consistent with the presence of some isolated palm trees as noted by the first Europeans reaching the island during the $18^{\text {th }}$ century (Zizka, 1991, Hunt, 2007, Mann et al., 2008). The progressive palm decline observed in our results is at variance with earlier studies that have proposed a sudden and rapid vegetation change, i.e. a catastrophic palm forest demise (Flenley and King, 1984, Flenley et al., 1991, Mann et al., 2008). In these studies, which were also performed in the Lake Raraku sediments, palm pollen sharply declines and is replaced abruptly by grass pollen, probably as a result of sedimentary gaps masking the trends shown by our data.

Of the three recorded palm declines, only the second can be linked to a sedimentary gap ( $\sim \mathrm{AD}$ 500 to $\sim \mathrm{AD} 1200$ ), which is interpreted as indicative of dry climates (Fig. 6). This would suggest some influence of climate on the palm demise. However, the decline occurred immediately after the hiatus, coinciding with the transition between lower and higher water levels, as indicated by diatoms, and also by a marked increase in charcoal, which strongly suggests human disturbance. It may be that the vegetation change was brought about by a combination of climatic and anthropogenic forcings. Dry climates would have depleted natural resources and favoured vegetation ignitability, leading to an intensification of forest exploitation and local burning. The first and third palm declines occurred without evidence of significant climate change. The first decline took place within a lowstand phase and coincides with increases in charcoal and herbs, suggesting human disturbance. However, there is no evidence of human occupation of Easter Island at that time. This possibility is discussed in the next section (5.3) on the basis of new evidence provided in this paper. The 
last palm decline occurred in a highstand situation (i.e. wetter climates) and is coeval with a second notable increase in charcoal influx, which strongly suggests intensification of burning. The second sedimentary gap (c. AD 1570 to c. AD 1720) does not appear to have affected the vegetation significantly.

In the two last centuries, floristic and vegetation changes consisted in the introduction of allochthonous plants, such as Eucalyptus and Psidum guajava, and the disappearance of native ones as is the case of Sophora (Figs. 4 and 6). The last appearance of Sophora in the record roughly coincides with the onset of sheep farming on the island (Porteus, 1978, Mieth and Bork, 2005). It is well documented that sheep farming at the end of the $19^{\text {th }}$ century and throughout $20^{\text {th }}$ century intensified the degradation of the landscape (Porteus, 1978, Mieth and Bork, 2005), which would have contributed to the extinction of Sophora. The indigenous vegetation of Easter Island has been relegated to a few isolated locations and have been mainly replaced by allochtonous grasses and other introduced plants (Zizka, 1991).

\subsection{Verbena litoralis colonisation and expansion.}

The decline of palm forest was accompanied by the expansion of herbs, mainly Poaceae and Verbena litoralis. The presence of the pollen of the Verbena litoralis in the sedimentary records of Easter Island has not been documented to date, although this plant forms part of the present vegetation. $V$. litoralis is a native species of America commonly associated with disturbed sites (agricultural or ruderal) (Zizka, 1991, Wagner et al. 1999) and is considered to have been introduced to the island during the two last centuries (Zizka, 1991). The continued and predominant occurrence of Verbena litoralis pollen, and its trends over time, in the Raraku record from $450 \mathrm{BC}$ could be due a priori to three causes: 1) arrival of the plant in the island by non-human (natural) dispersal mechanisms, such as birds or rafting, and establishment and expansion as a result of favourable environmental conditions; 2) arrival by natural dispersal agents but spreading and expansion as a result of human activities and 3) arrival, establishment and population expansion linked to human activities.

In the first case, the onset of herb expansion coinciding with the first palm decline would have been due to environmental, probably climatic, causes. According to this hypothesis, palm forests were already decaying when humans colonised the island. A scenario of this type was suggested by Hunter-Anderson (1998), who proposed a geo-climatic model to account for the disappearance of the palms in which mid to late-Holocene climatic instability would have played a major role. According to this author, humans arrived in the island during "favourable conditions of the Little Climatic Optimum" between AD 800 and AD 1400 (1200 and $600 \mathrm{yr}$ BP), when the island was already covered by grasses with only few trees and shrubs growing at 
protected sites. Likewise, droughts and changes in ENSO frequency have been proposed as possible causal agents for vegetation changes by other authors (Orliac and Orliac, 1998, Orliac, 2000, Nunn, 2000, Nunn and Britton, 2001). However, no conclusive evidence has been obtained to date. This hypothesis has been dismissed using inferences from the climate dynamics of the last 50 years (MacIntyre, 2001, Genz and Hunt, 2003). There is no independent evidence in the palynological record to either support or challenge this hypothesis (Rull et al., 2010). Other possible causal agents of vegetation change could have been short-term perturbations such as intense storms. The continuous nature of the trend of change observed in our records does not appear to support the occurrence of episodic events as potential causes.

The two other hypotheses attribute the expansion of Verbena litoralis and the associated landscape transformations to human activities. Both hypotheses suggest human presence on the island to at least $\sim 450 \mathrm{BC}$, some 1500 years before the commonly accepted date (discussion in section 5.4). The main difference between these two hypotheses is the dispersal agent responsible for the transportation of the plant to the island, either by non-human agents (hypothesis two) or by the eventual first colonisers (hypothesis three). As stated above, Verbena litoralis, which is commonly associated with human activities, it is also regarded as a weed. At present, the species is well established on the island, especially along waysides, coasts and lake shores (Zizka, 1991). Moreover, it has been suggested that V. litoralis (known as "puringa" by present-day Easter Islanders) was cultivated on the island in historical times for its medicinal properties (Zizka, 1991, Rauch et al., 1996), which could have favoured the spread of this herb. Therefore, the relationship between this plant and human activities seems, at present, fairly clear.

The Raraku record shows a significant correlation between charcoal and V. litoralis $(\mathrm{r}=0.61$, pvalue $=0.003)$, and between charcoal and herbs (basically $V$. litoralis + Poaceae $)(r=0.70, p-$ value $=0.0004$ ), which highlights a relevant role of fire in the replacement of palms by open vegetation and with the expansion of $V$. litoralis. This indirectly supports the role of humans through burning in the vegetation changes of the last millennia. Indeed, vegetation clearance, which has been associated with high increases in charcoal influx and grasses, sedges and ferns at the expense of trees, has been commonly attributed to human activities on Easter Island and on many other Pacific islands (e.g. Kirch, 1986, McGlone and Wilmshurst, 1999, Anderson, 2002, Kennett et al., 2006). In this regard, the initial spread of the V. litoralis (and Poaceae too), which occurred c. $450 \mathrm{BC}$, was probably the result of a low environmental impact caused by a small human population during the initial settlement. Further $V$. litoralis and grass expansions would have been favoured by the continued population growth and intensification of agriculture. Numerous studies have reported intensive agricultural practices on Easter Island 
c.AD 1200-1600 (e.g. Stevenson, 1997, Stevenson et al., 2002, Mieth and Bork, 2005).

Recently, Horrocks et al. (2012) have suggested that the Lake Raraku crater was also intensively multi-cropped. Our results support the interpretation of the intensification of human impact $\mathrm{c}$.

AD 1200. They confirm a highly modified landscape surrounding Lake Raraku as evidenced by the striking abundance of Verbena litoralis and herbs, the marked decrease in palms and the increase in charcoal influx. Moreover, the presence of diatoms of the genus Fragilaria s.l. indicates enhanced runoff and cation input to lake waters, also suggesting increased catchment erosion at that time.

Finally, the pattern of ecological transformation is continuous and irreversible, which is consistent with the action of a persistent forcing mechanism hampering an eventual vegetation recovery. Overall, these changes strongly support the role of humans in landscape transformation since c. $450 \mathrm{BC}$.

\subsection{Early human settlement and potential origins}

Our results show that vegetation change starts c. $450 \mathrm{BC}(790 \mathrm{BC}-90 \mathrm{BC})$ according to the age-depth model inferred, which is about 1500 years before the date generally accepted for palm decline as well as for the arrival of Polynesian settlers. The first archaeological works on Easter Island suggest that the initial human settlement took place around AD 400 (Heyerdahl and Ferdon, 1961). Further palynological works have proposed that human arrival and initial deforestation occurred c. AD 750-1200 (Flenley and King, 1984, Flenley et al., 1991, Flenley, 1993), and that island deforestation was complete by AD 1500 (Flenley, 1993). However, an earlier date of c. AD 300 for colonisation has been subsequently put forward (Flenley, 1996). Increasing archaeological work and the reanalysis of previous radiocarbon dates led to Martinsson-Wallin and Crockford (2002) to propose the interval AD 800-1200 as the most reliable date for the first human settlements, which is currently the most commonly accepted date (Vargas et al., 2006). Nevertheless, earlier and later dates for these events have also been proposed since then. Hunt and Lipo (2006) proposed that the colonization occurred around AD 1200, a date supported by deforestation records according to Mann et al. (2008). Recently, even later dates, around AD 1200-1290 have been suggested (Wilmshurst et al., 2011). The earliest date proposed to date has been AD 50-100 (1900 cal yr BP) (Butler and Flenley, 2010). These authors speculated about human presence at this date on the basis of a charcoal peak and a short palm pollen decline at Lake Kau. The evidence proved to be inconclusive because the palm pollen showed a rapid recovery and because it was not possible to ascertain whether the fires were of human or natural origin (Butler and Flenley, 2010). 
These different chronologies of settlement on Easter Island are also significant as regards the debate on the timing of the eastward spread of Polynesians across the Pacific. A definitive consensus remains to be achieved on many islands including Easter Island. Divergent settlement chronologies that vary by more than 1000 years coexist (Kirch and Kahn, 2007, Wilmshurst et al., 2008). This precludes the knowledge of the regional pattern of settlement (Wilmshurst et al., 2011). Most researchers accept the existence of a "long pause" of several centuries to a millennium between the initial Lapita settlement on Tonga-Samoa (occurred during the first or second millennia $\mathrm{BC}$ ) and the subsequent expansion of the Polynesian population to the east (Kirch and Kahn, 2007, Wilmshurst et al., 2011) (figure 1). The most accepted view is that the initial colonisation of central Polynesia (including Marquesas and Society Islands) followed by the settlements in remote islands occurred c. AD 300-900 (Kirch and Kahn, 2007, Wilmshurst et al., 2011), although a recent work suggests later dates (AD 1025-1120) (Wilmshurst et al., 2011). Our results, which suggest early human presence, would give further support to older chronologies of the eastward spread of the Polynesians without a pause or with only a short time lag between the colonisation of West and East Polynesia.

Another classic controversy concerns the American or Polynesian origin of the first Easter Island settlers. Several lines of evidence (cultural, archaeological and genetic) suggest that the modern islanders are descended from Polynesians (Flenley et al., 1991, Hagelberg et al., 1994, van Tilburg, 1994, Flenley and Bahn, 2003). They probably came from some French Polynesian archipelago situated $>2000 \mathrm{~km} \mathrm{W-NW}$ (Flenley and Bahn, 2003) (figure 8). Nevertheless, the American origin of Verbena litoralis and its continued presence during the last millennia revives the idea of a possible role of American elements in the history of Easter Island. Heyerdahl and Ferdon (1961) were the first to formally suggest that the island was colonised initially by Amerindians. Their hypothesis was founded on the possibility that travel from South America to Easter Island was favoured by dominant currents and winds, and on the similarity of some archaeological elements. On other hand, Gill (1998) proposed that the settlement of Easter Island was the result of a two-stage process of colonisation from East Polynesia to America and then to Easter Island. These hypotheses have been ruled out for lack of conclusive evidence (Flenley and Bahn, 2003). However, evidence does exist in support of a prehistoric contact between South American and Polynesian peoples, although when and where this occurred is unclear. Evidence for this contact includes the prehistoric introduction of South American crops such as sweet potato (Ipomoea batatas (L.) Lamarck) and the bottle gourd (Lagenaria siceraria (Molina) Standley) to Polynesia (Green, 2005, Clarke et al., 2006), and the pre-Columbian introduction of Polynesian chickens to Chile (Storey et al., 2007). The most accepted view is that Polynesians would have reached the American continent and later come back to Polynesia. However, some archaeological works have emphasised the capacity of Amerindian societies for 
long distance oceanic travelling (Montenegro et al., 2008) and potential long voyages of Amerindians have been also proposed (Dumont et al., 1998, Montenegro et al., 2008).

The Polynesian origin of the modern Easter Islanders is not incompatible with a short-lived American influence. In this regard, recent studies in molecular genetics have shown a prehistoric Amerindian contribution to the human gene pool of Easter Islanders although after Polynesian settlement (Thorsby, 2012). Possible hypotheses to be tested by future studies in the light of our results include: 1) the eventual presence on the island of a small Amerindian population that disappeared after the Polynesian arrival or was assimilated into the subsequent settlers, and 2) the possible arrival of a Polynesian group from America (figure 8).

Alternatively, as stated before, the Verbena litoralis could have reached the island through natural vectors, as is the case of other plants of American origin (e.g., Scirpus californicus) (Zizka, 1991). Our study shows that, despite the absence of conclusive evidence, further research is warranted to support or challenge these possibilities.

\section{Conclusions and final remarks}

This multiproxy study of a Lake Raraku core (Easter Island) shows that climate and, especially, human activities have brought about significant environmental and vegetation changes during the last millennia. From c. 1790 to c. 450 BC, a mire covered the bottom of the Raraku crater, which was surrounded by a wooded landscape dominated by palms. The first landscape opening occurred c. $450 \mathrm{BC}$, as evidenced by the palm decline and the increase in herbs (mainly Poaceae and the weed Verbena litoralis). This change coincided with a slight charcoal increase, and may indicate human arrival in the island. The presence of a sedimentary gap (c. AD 500 to c. AD 1165 ) would indicate drought phases that could be related to some dry phases of the Medieval Climatic Anomaly. The bottom of the Raraku crater was flooded again c. AD 1200, which resulted in a shallow lake. This suggests a higher precipitation/evaporation ratio that could match the AD 1300 event, a pan-Pacific phase of rapid cooling and wetter conditions. At c. AD 1200 , a second step of vegetation clearance took place, and herbs became progressively dominant, coinciding with further increases in fire incidence, which suggests an intensification of human impact. From c. AD 1475 to c. AD 1875, the landscape was probably almost entirely dominated by herb communities, with abundant $V$. litoralis, and a few scattered palms. The highest frequency of burning is observed during this period. A short hiatus (c. AD 1570 to c. AD 1720) interrupted sedimentation, indicating a new drought phase. This could be related to drought events during the Little Ice Age. Since c. AD 1875, grass communities have proliferated and several allochthonous plants have been introduced and have spread at the expense of native ones. 
Shorter sedimentary gaps in our study than those obtained in earlier works provide a more comprehensive record of ecological and sedimentary changes. Our results show that the replacement of the palm-dominated vegetation by herb-dominant communities was a long, gradual and stepped process. This is in sharp contrast to the commonly accepted scenario of a catastrophic vegetation change, resulting in sudden and rapid deforestation. According to our data, the vegetation change started c. $450 \mathrm{yr}$ BC, some $1500 \mathrm{yr}$ earlier than the accepted date. On the other hand, the expansion of the weed V. litoralis, which is linked to the palm demise, suggests a relationship between human activities and early landscape modification. This hypothesis is also supported by notable increases in charcoal. Moreover, the significant correlation of herbs with charcoal values suggests that burning played a prominent role in shaping the landscape. Further studies on sedimentary cores from other sites of the island are warranted to ascertain whether the observed changes are local or more widespread on the Island. Our data suggest that human presence on Easter Island may be significantly older than commonly accepted, which would have far-reaching implications for the Pacific colonisation chronologies. The American origin of $V$. litoralis precludes the rejection of the possibility of an early American influence on Easter Island history. In light of the results obtained, several hypotheses to be tested with future studies are erected.

\section{Acknowledgements}

This work was supported by funding from the Spanish Ministry of Science and Education through the projects LAVOLTER (CGL2004-00683/ BTE), GEOBILA (CGL2007-60932/BTE) and CONSOLIDER GRACCIE (CSD2007-00067) and through an undergraduate grant (BES2008-002938 to N. Cañellas-Boltà). We gratefully acknowledge CONAF (Chile) and the Riroroko family for the facilities provided on Easter Island. We also thank Josep Vigo for the identification of Verbena litoralis and Arturo Morales for his assistance in the identification of the small Pseudostaurosira species. Grateful thanks are also due to Raymond Bradley, José Carrión, William Gosling and Peter Kershaw for their critical revision of an earlier version of the manuscript.

\section{REFERENCES}

Anderson, A., 2002. Faunal collapse, landscape change and settlement history in Remote Oceania. World Archaeology 33 (3), 375-790.

Axford, Y., Briner, J.P, Cooke, C.A., Francis, D.R., Michelutti, N., Miller, G.H., Smol, J.P., Thomas, E.K., Wilson, C.R., Wolfe, A.P., 2009. Recent changes in a remote Arctic lake are unique within the past 200,000 years. PNAS 106, 18443-18446. 
Azizi, G., Flenley, J.R., 2008. The last glacial maximum climatic conditions on Easter Island. Quaternary International 184 (1), 166-176.

Baker, P.E., Buckley, F., Holland, J.G., 1974. Petrology and Geochemistry of Easter Island. Contributions to Mineralogy and Petrology 44, 85-100.

Bennett, K.D., 1996. Determination of the number of zones in a biostratigraphical sequence. New Phytologist 132, 155-170.

Bennett, K.D., 2009. Documentation for Psimpoll 4.10 and Pscomb 1.03, C Programs for Plotting Pollen Diagrams and Analysing Pollen Data. Uppsala University. Uppsala. Update to v 4.27. http://www.chrono.qub.ac.uk/psimpoll/psimpoll.html

Blaauw, M., Christen, J.A., 2011. Flexible paleoclimate age-depth models using an autoregressive gamma process. Bayesian Analysis 6, 457-474.

Butler, K.R., Flenley, J.R., 2010. The Rano Kau 2 pollen diagram: Paleoecology revealed. Rapa Nui Journal 24 (1), 5-10.

Butler, K., Prior, C.A., Flenley, J.R., 2004. Anomalous radiocarbon dates from Easter Island. Radiocarbon 46, 395-405.

Cañellas-Boltà, N., Rull, V., Sáez, A., Margalef, O., Giralt, S., Pueyo, J.J., Birks, H.H., Birks, H.J.B., Pla-Rabes, S., 2012. Macrofossils in Raraku Lake (Easter Island) integrated with sedimentary and geochemical records: towards a palaeoecological synthesis of the last 34,000 years. Quaternary Science Reviews 34, 113-126.

Christen, J.A., Pérez E., S., 2009. A New Robust Statistical Model for Radiocarbon Data. Radiocarbon 51 (3), 1047-1059.

Clarke, A.C., Burtenshaw, M.K., McLenachan, P.A., Erickson, D.L., Smith, B.D., Penny, D., 2006. Reconstructing the origins and dispersal of the polynesian bottle gourd (Lagenaria siceraria). Molecular Biology and Evolution 23, 893-900.

Denys, L., 1991. A check-list of the diatoms in the Holocene deposits of the western Belgian coastal plain with a survey of their apparent ecological requirements. I. Introduction, ecological code and complete list. Belg. Geol. Dienst, Prof. Paper 246, 1-41.

Diamond, J., 2005. Collapse. How societies choose to fail or survive. Allen Lane, London.

Dumont, H.J., Cocquyt, C., Fontugne, M., Arnold, M., Reyss, J.-L., Bloemendal, J.,Oldfield, F., Steenbergen, C.L.M., Korthals, H.J., Zeeb, B.A., 1998. The end of moai quarrying and its effect on Rano Raraku, Easter Island. Journal of Paleolimnology 20, 409-422.

Elix, J. A., McCarthy, P. M., 2008. Checklist of Pacific Island Lichens. Australian Biological Resources Study, Canberra. Version 21 August 2008.

http://www.anbg.gov.au/abrs/lichenlist/Pacific_introduction.html

Flenley, J.R., 1993. The palaeoecology of Easter Island, and its ecological disaster. In: Fischer, S.R. (Ed.), Easter Island Studies: Contribution to the History of Rapanui in Memory of William T. Mulloy. The Short Run Press, Oxbow, Oxford, pp. 27-45.

Flenley, J. R., 1996. Further Evidence of Vegetation Change on Easter Island. South Pacific Studies 16 (2), 135-141. 
Flenley, J.R., Bahn, P., 2003. The Enigmas of Easter Island. Island on the Edge. Oxford University Press. New York.

Flenley, J.R., King, S.M., 1984. Late Quaternary pollen records from Easter Island. Nature 307, 47-50.

Flenley, J.R., King, S.M., Jackson, J., Chew, C., Teller, J.T., Prentice, M.E., 1991. The late Quaternary vegetational and climatic history of Easter Island. Journal of Quaternary Science 6 (2), 85-115.

Geller, W., 1992. The temperature stratification and related characteristics of Chilean lakes in midsummer. Aquatic Sciences 54 (1), 37-57.

Genz, J., Hunt, T.L., 2003. El Niño/southern oscillations and Rapa Nui prehistory. Rapa Nui Journal 17, 7-14.

Gill, G.W., 1998. Easter Island Settlement: Current Evidence and Further Research Directions. In. Stevenson, C., Lee, G., Morin, F.J. (Eds.), Easter Island in Pacific Context: South Seas Symposium. Proceedings of the Fourth International Conference on Easter Island and East Polynesia. The Easter Island Foundation, Los Osos (CA). pp. 137-142

González-Ferran, O., Mazzuoli, R., Lahsen, A., 2004. Geología del Complejo Volcánico Isla de Pascua Rapa Nui, Chile. Carta Geológica-Volcánica". Centro de Estudios Volcánologicos (ed.), Santiago-Chile. 1:30.000 Geol. map

Green, R.C. 2005. Sweet potato transfers in Polynesian prehistory. In Ballard, C., Brown, P., Rourke, R.M., Harwood, T. (Eds), The sweet potato in Oceania: a reappraisal. Oceania Monographs, Sydney, pp. 43-62.

Hagelberg, E., Quevedo, S., Turbon, D., Clegg, J.B., 1994. DNA from ancient Easter Islanders. Nature 369, 25-26.

Herrera, C., Custodio, E., 2008. Conceptual hydrogeological model of volcanic Easter Island (Chile) after chemical and isotopic surveys. Hydrogeology Journal 16, 1329-1348.

Heyerdahl, T., Ferdon, E.N., 1961. Reports of the Norwegian archaeological expedition to Easter Island and the East Pacific. Archaeology of Easter Island, Vol. 1. Forum Publishing House, Stokholm.

Horrocks, M.,Wozniak, J.A., 2008. Plant microfossil analysis reveals disturbed forest and mixed-crop, dryland production system at Te Niu, Easter Island. Journal of Archaeological Science 35, 126-142.

Horrocks, M, Baisden, W.T., Flenley, J., Feek, D., González Nualart, L, Haoa-Cardinali, S., Edmunds Gorman, T., 2012. Fossil plant remains at Rano Raraku, Easter Island's statue quarry: evidence for past elevated lake level and ancient Polynesian agriculture. Journal of Paleolimnology 48 (4), 767-783.

Hua, Q., Barbetti, M. 2004. Review of tropospheric bomb C-14 data for carbon cycle modeling and age calibration purposes. Radiocarbon 46 (3), 1273-1298.

Hunt, T.L., 2007. Rethinking Easter Island's ecological catastrophe. Journal of Archaeological Science 34, 485-502. 
Hunt, T.L., Lipo, C.P., 2006. Late colonization of Easter Island. Science 311, 1603-1606.

Hunt, T. L., Lipo, C. P. 2009. Revisiting Rapa Nui (Easter Island) "Ecocide”. Pacific Science 63 (4), 601-616.

Hunter-Anderson, R., 1998. Human vs. climatic impacts: did the Rapanui really cut down all those trees? In: Stevenson, C.M., Lee, G., Morin, F.J. (Eds.), Easter Island in Pacific Context: South Seas Symposium. Proceedings of the Fourth International Conference on Easter Island and East Polynesia. Easter Island Foundation, Los Osos, CA. pp. 85-99.

Johansen, J.R., 2010. Diatoms of aerial habitats. In Smol, J.P., Stoermer, E.F. (Eds.), The Diatoms: Applications for the Environmental and Earth Sciences. Cambridge University Press, Cambridge. pp. 465-472.

Kennett, D., Anderson, A., Prebble, M., Conte, E., Southon, J., 2006. Prehistoric human impacts on Rapa French Polynesia. Antiquity 80, 340-354.

Kirch, P.V., 1986. Rethinking East Polynesian prehistory. The journal of the Polynesian Society $95(1), 9-40$.

Kirch, P.V., Kahn, J.G., 2007. Advances in Polynesian Prehistory: a review and assessment of the Past Decade (1993-2004). Journal of Archaeological Research 15 (3), 191-238.

MacIntyre, F., 2001. ENSO, climate variability, and the Rapanui, part II. Oceanography and Rapa Nui. Rapa Nui Journal 15, 83-94.

Mann, D., Edwards, J., Chase, J., Beck, W., Reanier, R., Mass, M., Finney, B., Loret, J., 2008. Drought, vegetation change, and human history on Rapa Nui (Isla de Pascua, Easter Island). Quaternary Research 69, 16-28.

Martinsson-Wallin, H., Crockford, S.J., 2002. Early settlement of Rapa Nui (Easter Island). Asian Perspectives 40 (2), 244-278.

McCall, G., 1993. Little Ice Age, some speculations for Rapanui. Rapa Nui Journal 7(4), 65-70.

McCormac, F.G., Hogg, A.G., Blackwell, P.G., Buck, C.E., Higham, T.F.G., Reimer, P.J., 2004. SHCal04 Southern Hemisphere calibration 0-11.0 cal yr BP. Radiocarbon 46(3), 10871092.

McGlone, M.S., Wilmshurst, J. M. 1999. Dating initial Maori environmental impact in New Zealand. Quaternary International 59, 5-16.

Meyers, P.A., Terranes, J.L. 2001. Sediment organic matter. In Last, W., Smol J.P., (Eds). Tracking Enviromental Change Using Lake Sediments. vol. 2. Physical and Geochemical Techniques. Kluwer Academic Publishers, Dordrecht, The Netherlands. pp 239-269.

Mieth, A., Bork, H.R., 2005. History, origin and extent of soil erosion on Easter Island (Rapa Nui). Catena 63, 244-260.

Mieth, A., Bork, H.R., 2010. Human, climate or introduced rats - which is to blame for the woodland destruction on prehistoric Rapa Nui (Easter Island)? Journal of Archaeological Science 37, 417-426. 
Montenegro, A., Avis, C., Weaver, A., 2008. Modeling the prehistoric arrival of the sweet potato in Polynesia. Journal of Archaeological Science 35 (2), 355-367.

Nunn, P.D., 2000. Environmental catastrophe in the Pacific Islands around A.D. 1300. Geoarchaeology 15 (7), 715-740.

Nunn, P.D., 2007. Climate, Environment and Society in the Pacific during the last Millennium. Elsevier, Amsterdam, The Netherlands.

Nunn, P.D., Britton, J.M.R., 2001. Human-environment relationships in the Pacific islands around A.D. 1300. Environment and History 7, 3-22.

Orliac, C., 2000. The woody vegetation of Easter Island between the early 14th and the mid17th centuries AD. Easter Island archaeology. In: Stevenson, C.M., Ayres, W.S. (Eds.), Research on Early Rapanui Culture. Easter Island Foundation, Los Osos, pp. 211-220.

Orliac, C., Orliac, M., 1998. The disappearance of Easter Island's forest: overexploitation or climatic catastrophe? In: Stevenson, C., Lee, G., Morin, F.J. (Eds.), Easter Island in Pacific Context: South Seas Symposium. Proceedings of the Fourth International Conference on Easter Island and East Polynesia. Easter Island Foundation, Los Osos, pp. 129-134.

Porteous, J.D. 1978. Easter Island: the Scottish connection. Geographical Review 68(2), 145156.

R Development Core Team (2012). R: A language and environment for statistical computing. R Foundation for Statistical Computing, Vienna, Austria. ISBN 3-900051-07-0, URL http://www.R-project.org/

Rainbird, P., 2002. A message for our future? The Rapa Nui (Easter Island) ecodisaster and Pacific island environments. World Archaeology 33, 436-451.

Rauch, M., Ibañez, P., Ramírez, J.M., 1996. Vegetación de Rapanui, historia y uso tradicional. Ministerio de Agricultura. Corporación Nacional Forestal, Parque Nacional Rapa Nui. Chile

Reed, J.M., Roberts, N., Leng, M.J., 1999. An evaluation of the diatom response to Late Quaternary environmental change in two lakes in the Konya Basin, Turkey, by comparison with stable isotope data. Quaternary Science Reviews 18, 631-646.

Renberg, I., 1990. A procedure for preparing large sets of diatom slides from sediment cores. Journal of Paleolimnology 4, 87-90.

Rull, V., 1999. A palynological record of a secondary succession after fire in the Gran Sabana, Venezuela. Journal of Quaternary Science 14 (2), 137-152.

Rull, V., Rinaldi, M., 1988. Size variations of Kochia scoparia pollen under different treatments, mounting and storing media.

Rull, V., Cañellas-Boltà, N., Sáez, A., Giralt, S., Pla, S., Margalef, O., 2010. Paleoecology of Easter Island: evidence and uncertainties. Earth-Science Reviews 99, 50-60.

Rull, V., Stansell, N.D., Montoya, E., Bezada, M., Abbott, M.B. 2010b. Palynological signal of the Younger Dryas in tropical Venezuelan Andes. Quaternary Science Reviews 29, 3045-3056

Sáez, A., Valero-Garcés, B.L., Giralt, S., Moreno, A., Bao, R., Pueyo, J.J., Hernández, A., 
Casas, D., 2009. Glacial to Holocene climate changes in the SE Pacific. The Raraku Lake sedimentary record (Easter Island, $27^{\circ} \mathrm{S}$ ). Quaternary Science Reviews 28, 2743-2759.

Skottsberg, C. (Ed.), 1956. The Natural History of Juan Fernández and Easter Island. Almqvist \& Wiksells Boktryckeri, Uppsala.

Smol, J.P., 1985. The ratio of diatom frustules to chrysophycean statospores: a useful paleolimnological index. Hydrobiologia 123, 199-208.

Stefan, V., 2001. Origin and evolution of the Rapanui of Easter Island. In Stevenson, C.M., Lee, G., Morin, F.J. (Eds). Pacific 2000: Proceedings of the Fifth International Conference on Easter Island and the Pacific. Easter Island Foundation, Los Osos. pp. 495-522.

Stenseth, N.C., Voje K. L., 2009. Easter Island: climate change might have contributed to past cultural and societal changes. Climate Research 39, 111-114.

Stevenson, C.M., 1997. Archaeological investigations on Easter Island: Maunga Tari, an upland agricultural complex. Easter Island Occasional Paper 3. Bearsville Press and Cloud Mountain Press. Los Osos, CA.

Stevenson, C.M., Ladefoged, T., Haoa, S., 2002. Productive strategies in an uncertain environment: prehistoric agriculture on Easter Island. Rapa Nui Journal 16 (1), 17-22.

Storey, A.A., Ramírez, J.M., Quiroz, D., Burley, D.V., Addison, D.J., Walter, R., Anderson, A.J., Hunt, T.L., Athens, J.S., Huynen, L., Matisoo-Smith, E.A., 2007. Radiocarbon and DNA evidence for a pre-Columbian introduction of Polynesian chickens to Chile. Proceedings of the National Academy of Sciences USA 104, 10335-10339.

Thorsby, E., 2012. The Polynesian gene pool: an early contribution by Amerindians to Easter Island. Phil. Trans. R. Soc. B. 367, 812-819.

van Tilburg, J.A., 1994. Easter Island: Archaeology, Ecology and Culture. British Museum Press, London.

Vargas, P., Cristino, C., Izaurieta, R., 2006. 1000 años en Rapa Nui. Arqueología del asentamiento. Ed. Universitaria, Santiago de Chile.

Wagner, W.L., Herbst, D.R., Sohmer, S.H., 1999. Manual of the flowering plants of Hawaii. Revised edition. Bernice P. Bishop Museum special publication. University of Hawai'i Press/Bishop Museum Press, Honolulu.

Wilmshurst, J.M., Anderson, A. J., Higham, T.F.G., Worthy, T.H., 2008. Dating the late prehistoric dispersal of Polynesian to New Zealand using the commensal Pacific rat. PNAS 105, 7676-7680.

Wilmshurst, J. M., Hunt, T.L., Lipo, C.P., Anderson, A.J., 2011. High-precision radiocarbon dating shows recent and rapid initial human colonization of East Polynesia. PNAS 108, 18151820 .

Zizka, G., 1991. Flowering plants of Easter Island. Palmarum Hortus Francofurtensis Scientific Reports, Frankfurt am Main, Germany. 
Table 1. AMS ${ }^{14} \mathbf{C}$ Radiocarbon dates. Radiocarbon dates obtained from pollen-enriched extract from Raraku Lake core used for age-depth modelling

\begin{tabular}{llclcc}
\hline \multicolumn{1}{c}{ Sample name } & $\begin{array}{c}\text { Laboratory } \\
\text { name }\end{array}$ & $\begin{array}{c}\text { Depth } \\
(\mathbf{c m})\end{array}$ & Fraction dated & 14 C yr BP & \pm \\
\hline RAR 08-01-4 & Poz-42955 & 4 & Pollen-extract & $106.94 \pm 0.39$ pMC* \\
\hline RAR 08-01-09 & Poz-42957 & 9 & Pollen-extract & $101.03 \pm 0.35$ pMC* \\
\hline RAR 08-01-10-11 & Beta-316585 & 11 & Pollen-extract & 380 & 30 \\
\hline RAR 08-01-12-13 & Poz-32007 & 13 & Pollen-extract & 505 & 30 \\
\hline RAR 08-01-17 & Poz-42958 & 17 & Pollen-extract & 840 & 30 \\
\hline RAR 08-01-17-18 & Beta-316586 & 18 & Pollen-extract & 780 & 30 \\
\hline RAR 08-01-18-19 & Beta-316587 & 19 & Pollen-extract & 1180 & 30 \\
\hline RAR 08-01-21 & Poz-42959 & 21 & Pollen-extract & 2120 & 35 \\
\hline RAR 08-01-22-23 & Beta-316588 & 23 & Pollen-extract & 2970 & 30 \\
\hline RAR 08-01-25 & Poz-19940 & 25 & Pollen-extract & 2160 & 30 \\
\hline RAR 08-01-29 & Poz-42960 & 29 & Pollen-extract & 4800 & 35 \\
\hline RAR 08-01-40-41 & Poz-32120 & 41 & Pollen-extract & 4530 & 40 \\
\hline
\end{tabular}

*radiocarbon date post-bomb 
Figures captions

Figure 1. Map of Easter Island. Above: map of Easter Island showing the location of the three permanent water resources on the island (Rano Raraku and Rano Kau crater lakes and Rano Aroi fen). Below: the location of the island in the SE Pacific Ocean (map modified from Elix and McCarthy, 2008)

\section{Figure 2. Age-depth model for Lake Raraku sediment core developed by Bacon for the} interval studied here. A) Age-depth model and age distributions of calibrated ${ }^{14} \mathrm{C}$ dates. Line curve shows the best model, grey-scales indicate chronological uncertainties. The date at $25 \mathrm{~cm}$ depth appears too young when compared with the other dates and the model; this sample may have been contaminated by ingrowths of roots from peat above it. B) From top to bottom: (1) over 4,000 stored iterations show a stable MCMC run; Prior information (green curves) and posterior estimates (grey histograms) of (2) accumulation rates, (3) variability/memory of accumulation rate, and (4) hiatus sizes.

Figure 3. Lithology, physical and geochemical data. Physical and geochemical parameters from the Lake Raraku sequence. Lithostratigraphy and AMS ${ }^{14} \mathrm{C}$ radiocarbon dates are indicated on the left of the diagram. Dashed horizontal lines indicate sedimentary hiatuses.

\section{Figure 4. Pollen and charcoal diagram of the sequence from Lake Raraku. AMS ${ }^{14} \mathrm{C}$} radiocarbon dates are indicated on the left of the diagram and pollen zones are indicated on the right.

Figure 5. Diatom diagram of the sequence from Lake Raraku. AMS ${ }^{14} \mathrm{C}$ radiocarbon dates are indicated on the left of the diagram and diatom zones on the right.

Figure 6. Summary multiproxy diagram of the sequence from Lake Raraku. AMS ${ }^{14} \mathrm{C}$ radiocarbon dates are indicated on the left of the diagram, and calibrated dates according to the age model used on the right. The arrows in the Arecaceae curve indicate palm decline events discussed in the text. Dashed horizontal lines indicate phases identified in this study. The two sedimentary hiatuses in the sequence are depicted by horizontal lines. The sedimentary hiatuses observed in other studies are indicated on the right. Note that early human settlement (450 BC) and the gradual nature of ecological change fall within the hiatuses of earlier studies.

Figure 7. Photographs of a Verbena litoralis growing at present around Lake Raraku (A-D) and pollen identified as Verbena litoralis in the microscopic slides $(\mathrm{E}-\mathrm{H}) \mathrm{Bar}=10 \mu \mathrm{m}$. The slightly 
smaller size of fossil pollen is probably because of the use of silicone oil during pollen protocol and storage (Rull and Rinaldi, 1988).

Figure 8. Possible migration routes to Easter Island. Easter Island (EI) is indicated by a circle. A) Directly from French Polynesia. B) On a return voyage of French Polynesians from American. C) From America. Map modified from Storey et al. 2007. 


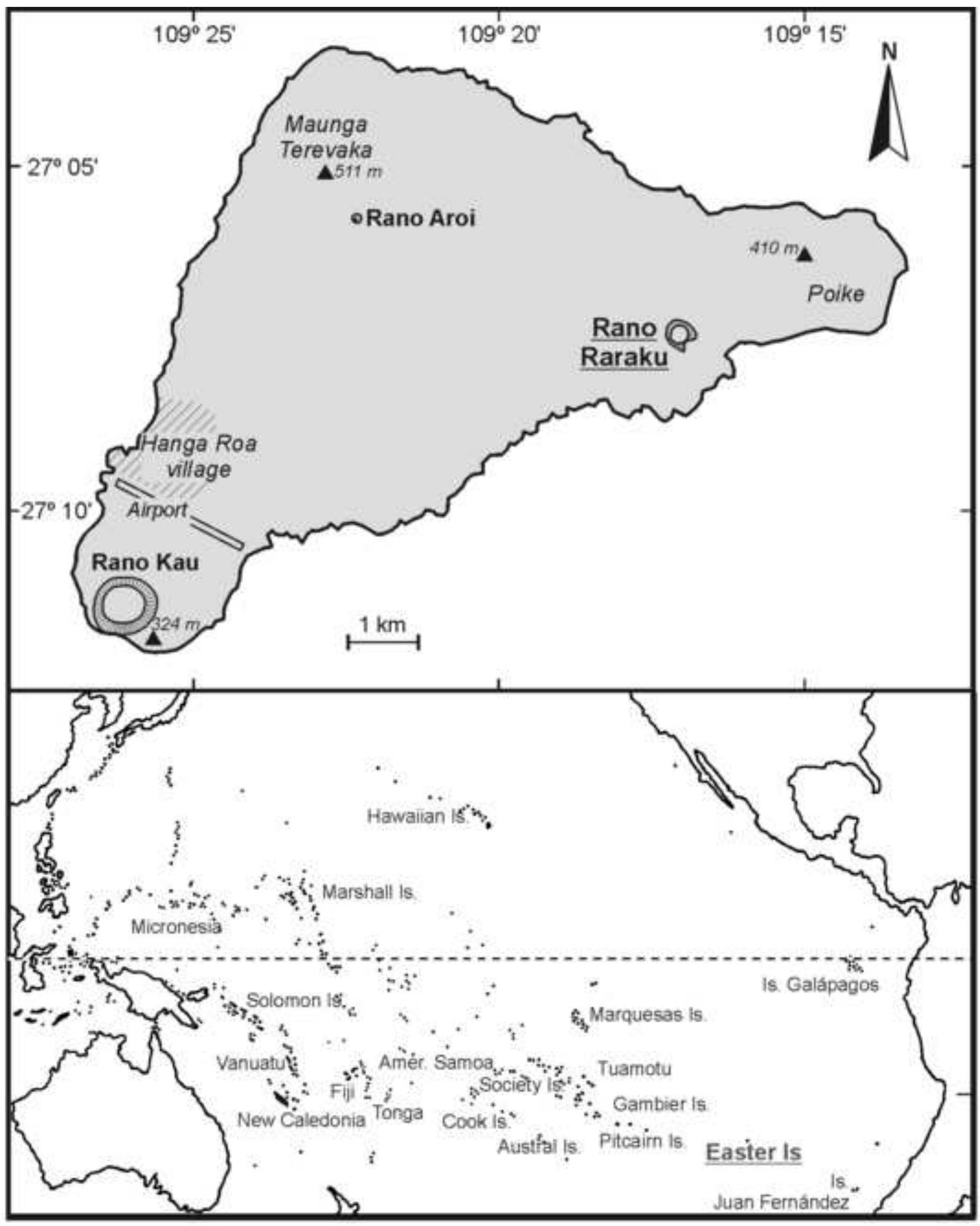




\section{Age-depth model}
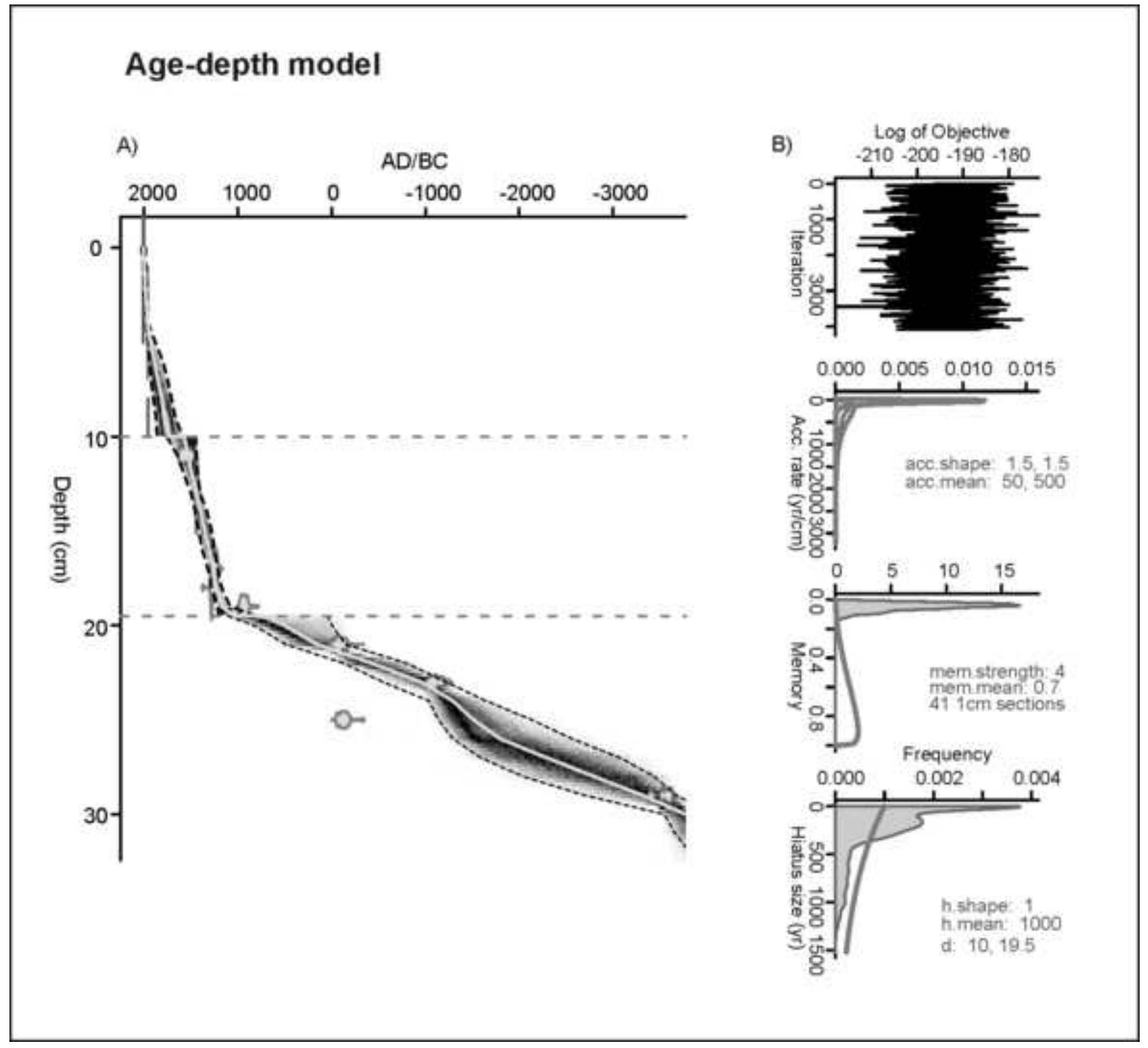

요원
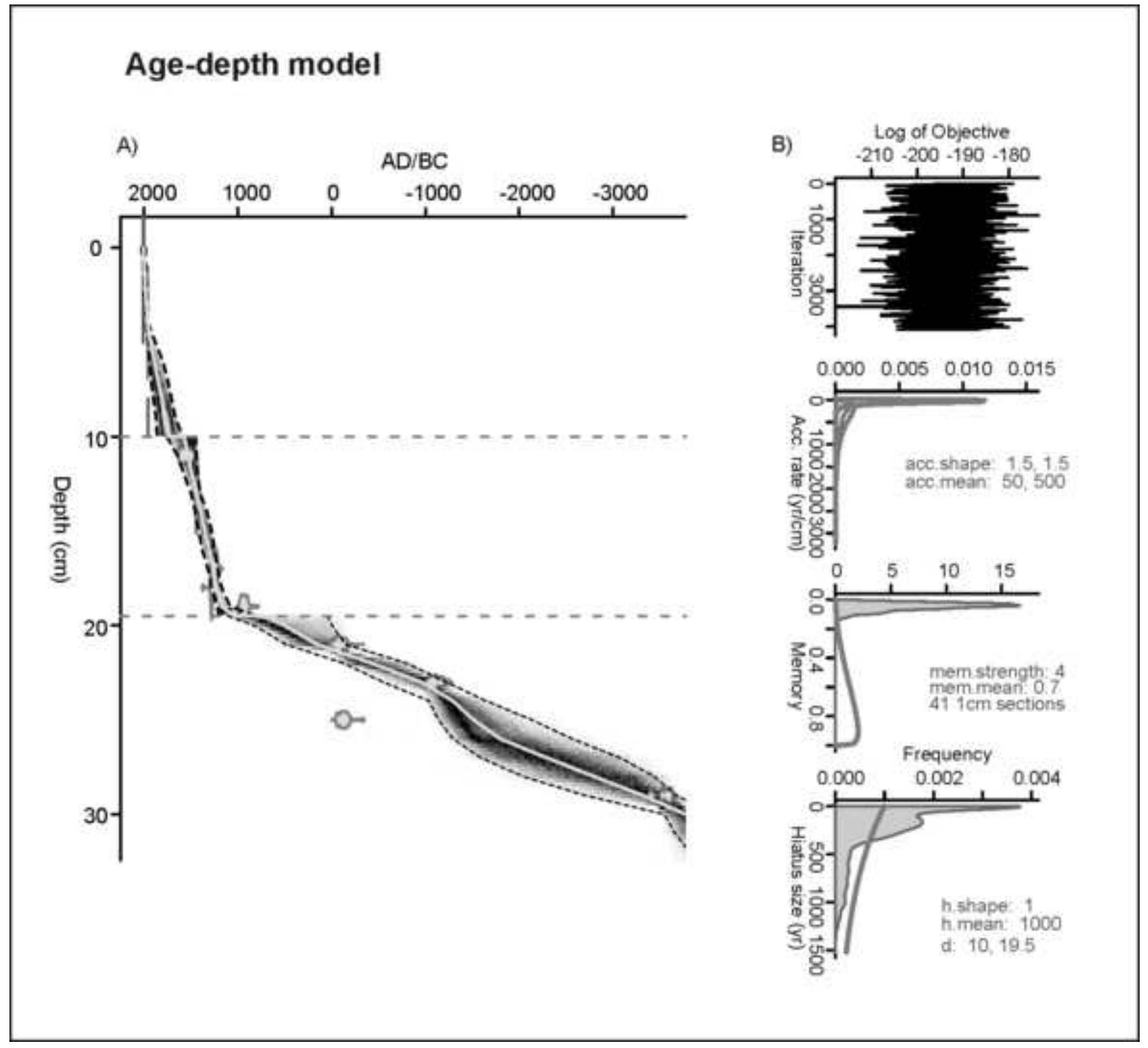

Click here to download high resolution image 


\section{Age-depth model}
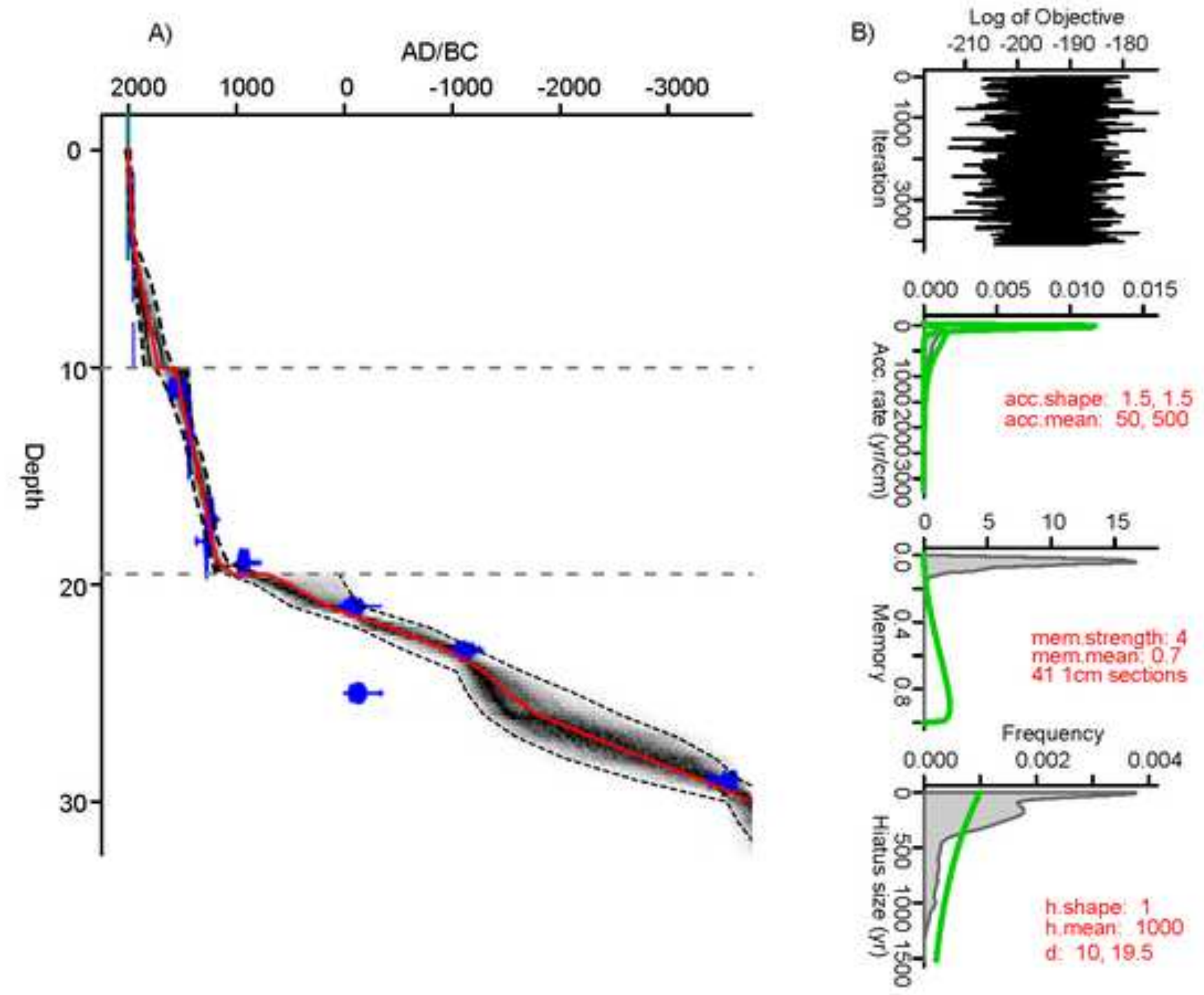
Click here to download high resolution image
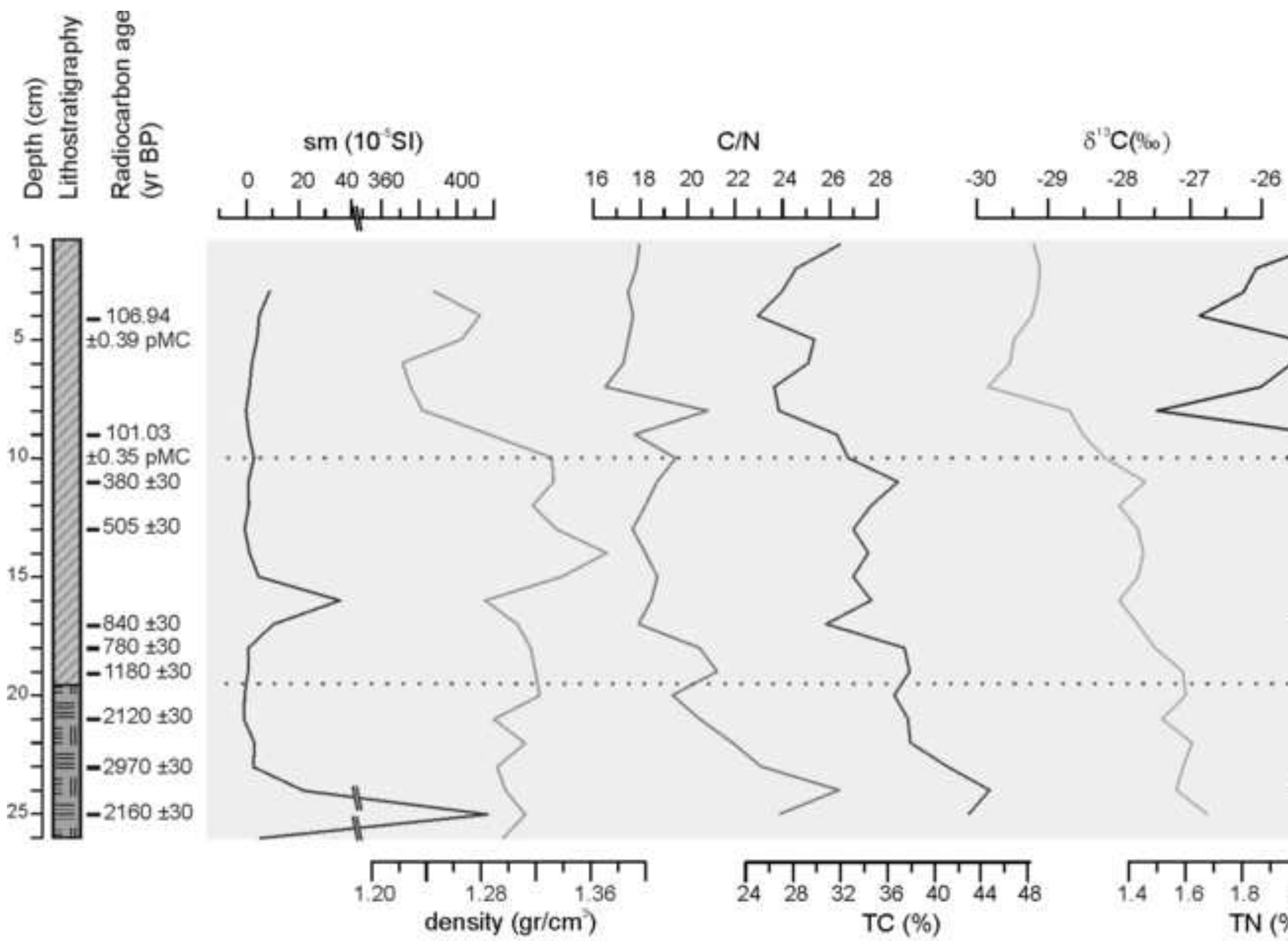

TC (\%)

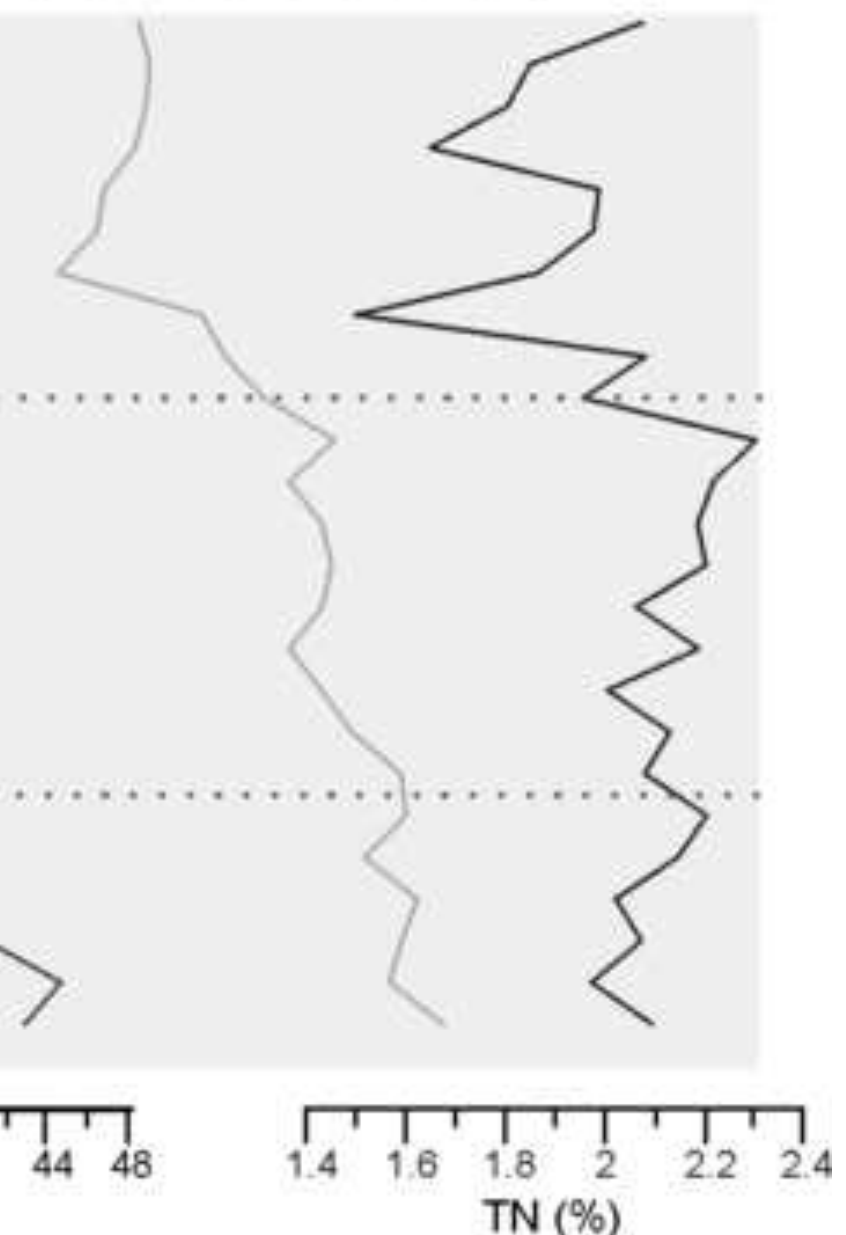

$\square$ Silty peaty sediment (lacustrine environment)

En Peaty sediment (mire environment) 
RAR 08: pollen, spores and charcoal Analyst. N Cañellast-Bolta

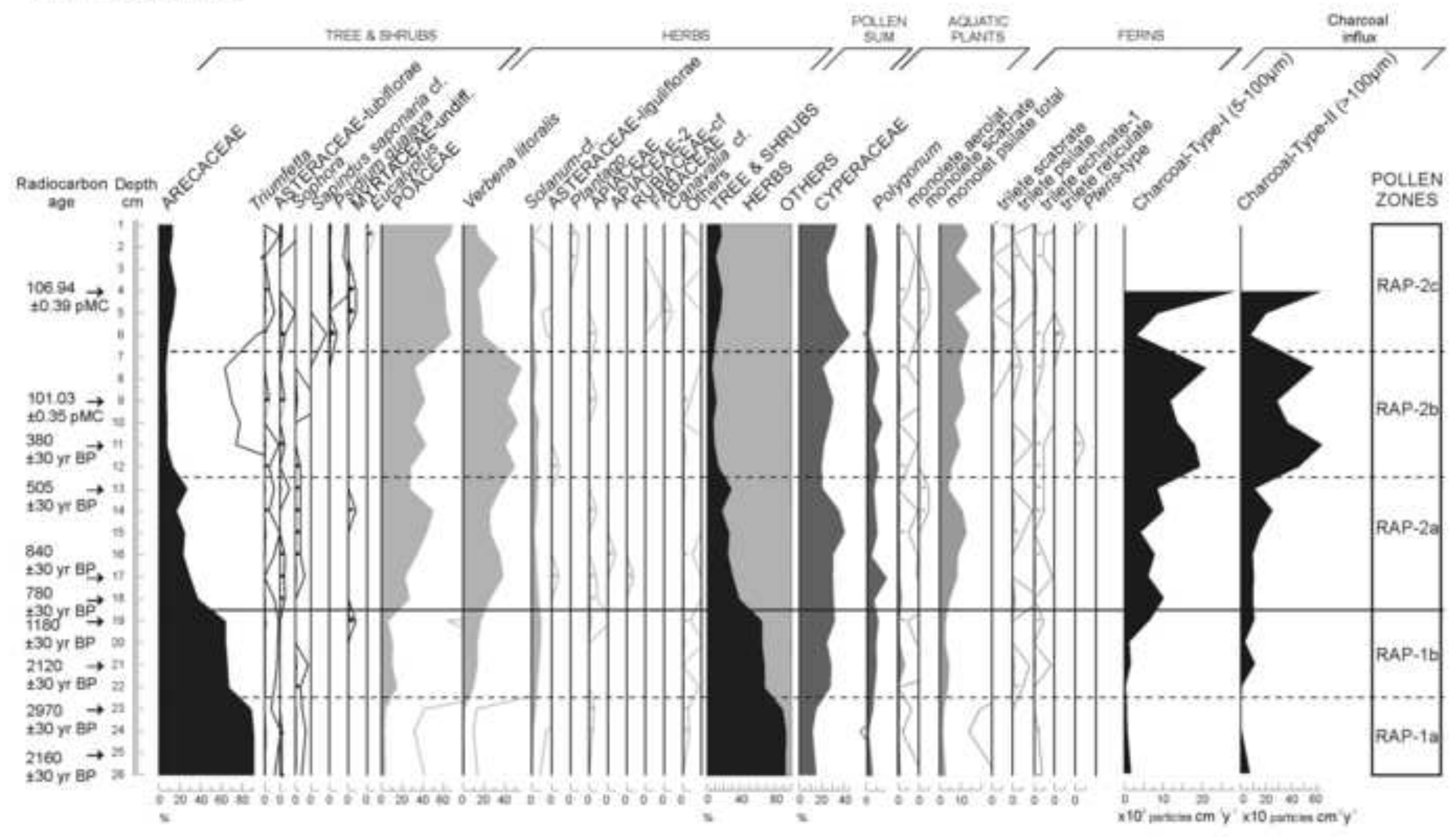




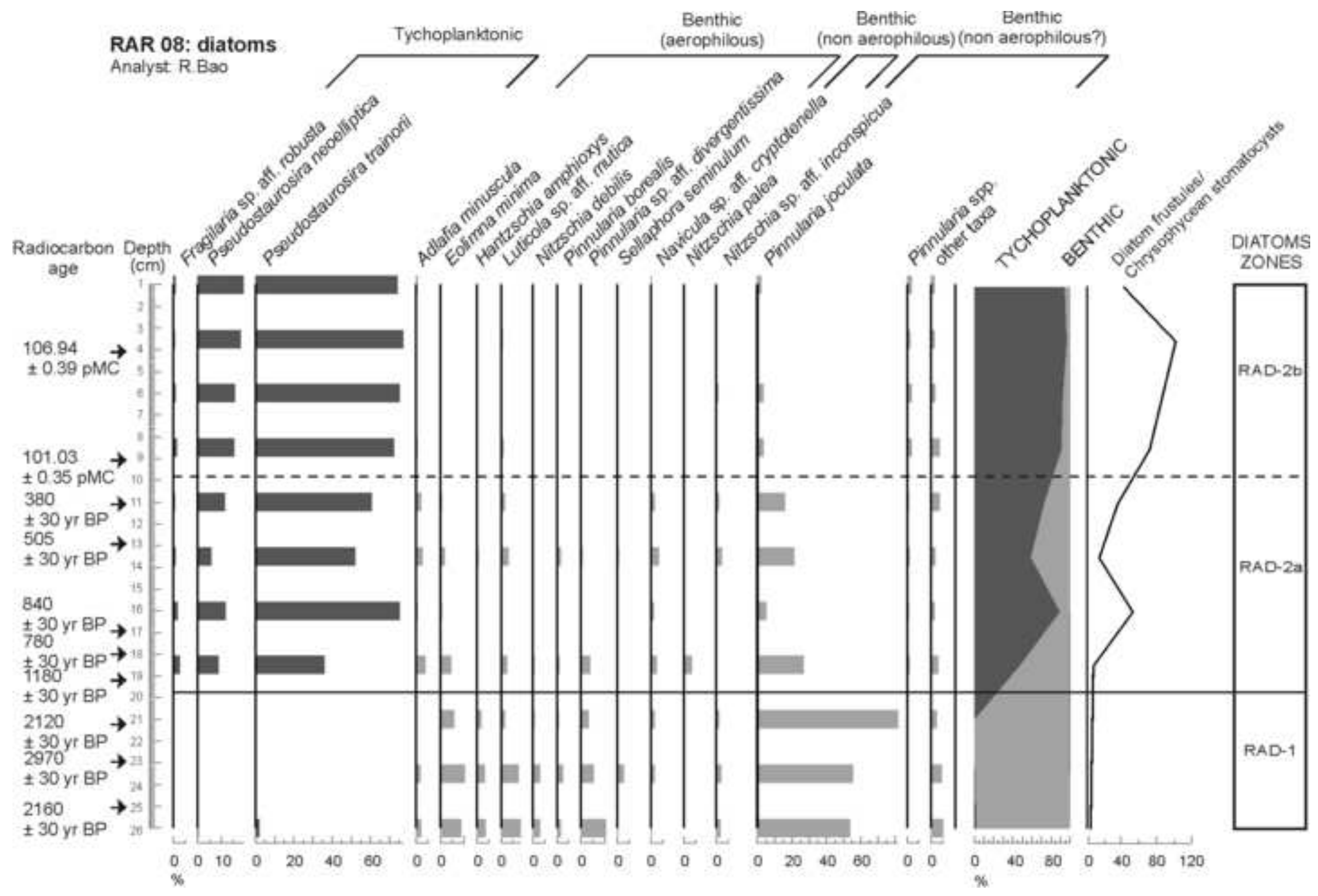




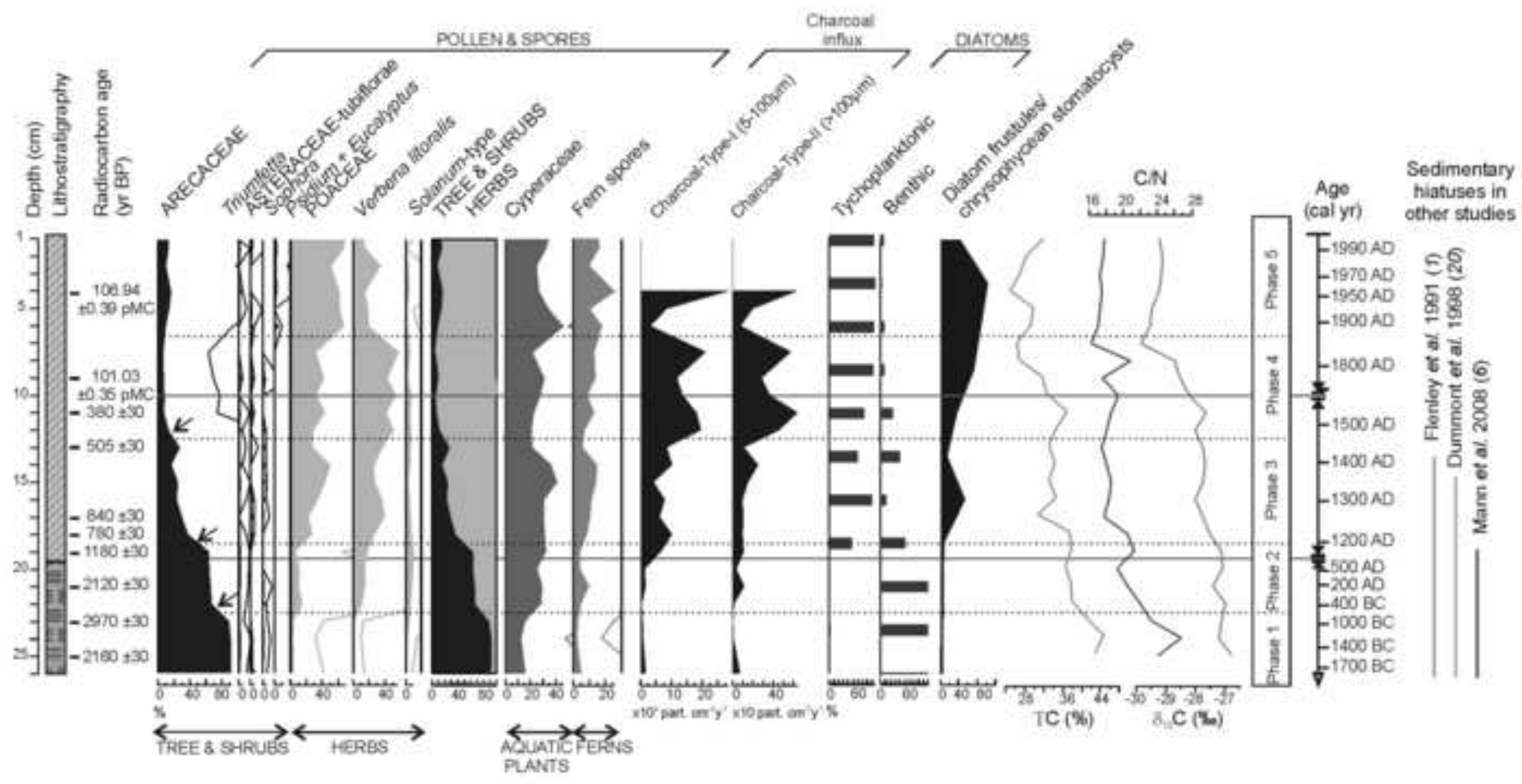

$\square$ Sity peaty sediment (boustrine environment)

Peaty sediment (mire environment) 

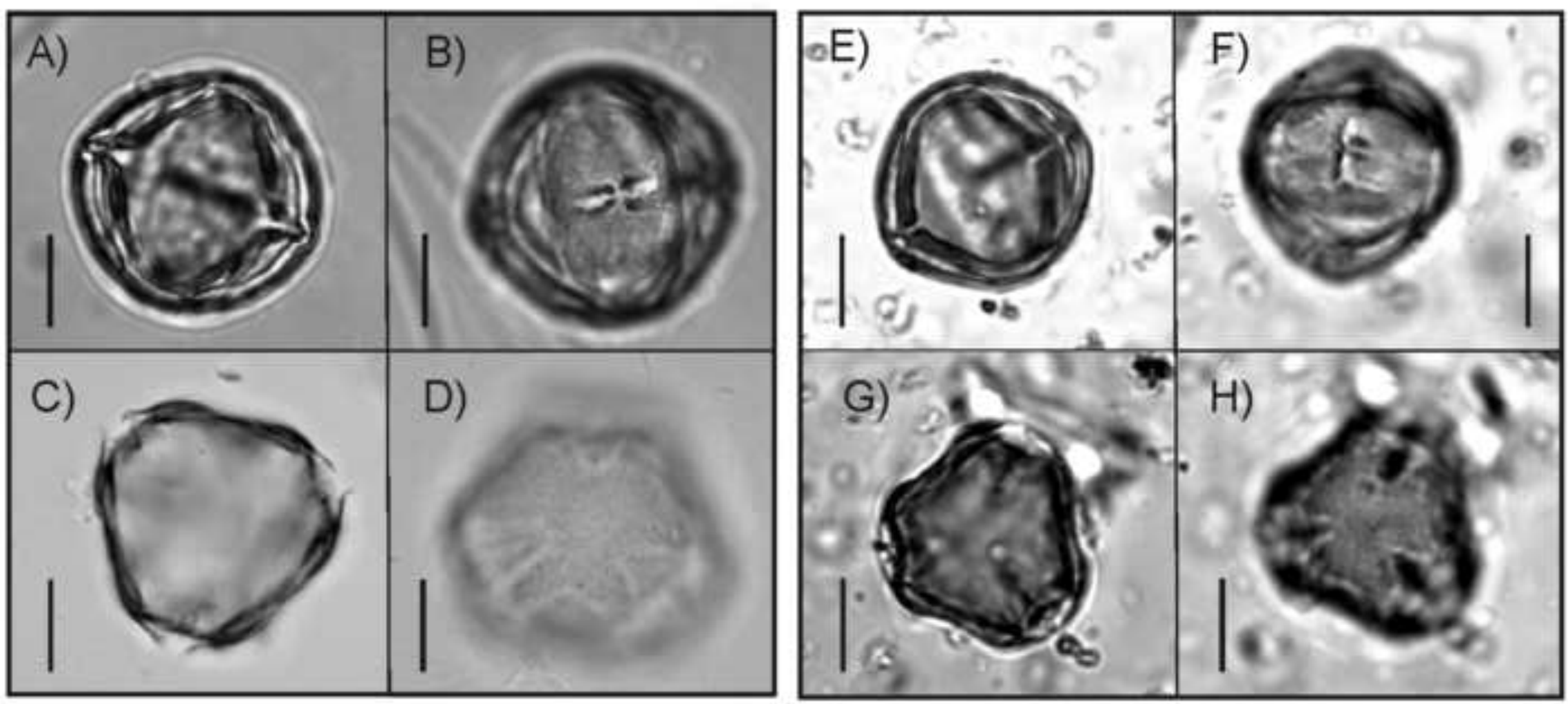
Click here to download high resolution image

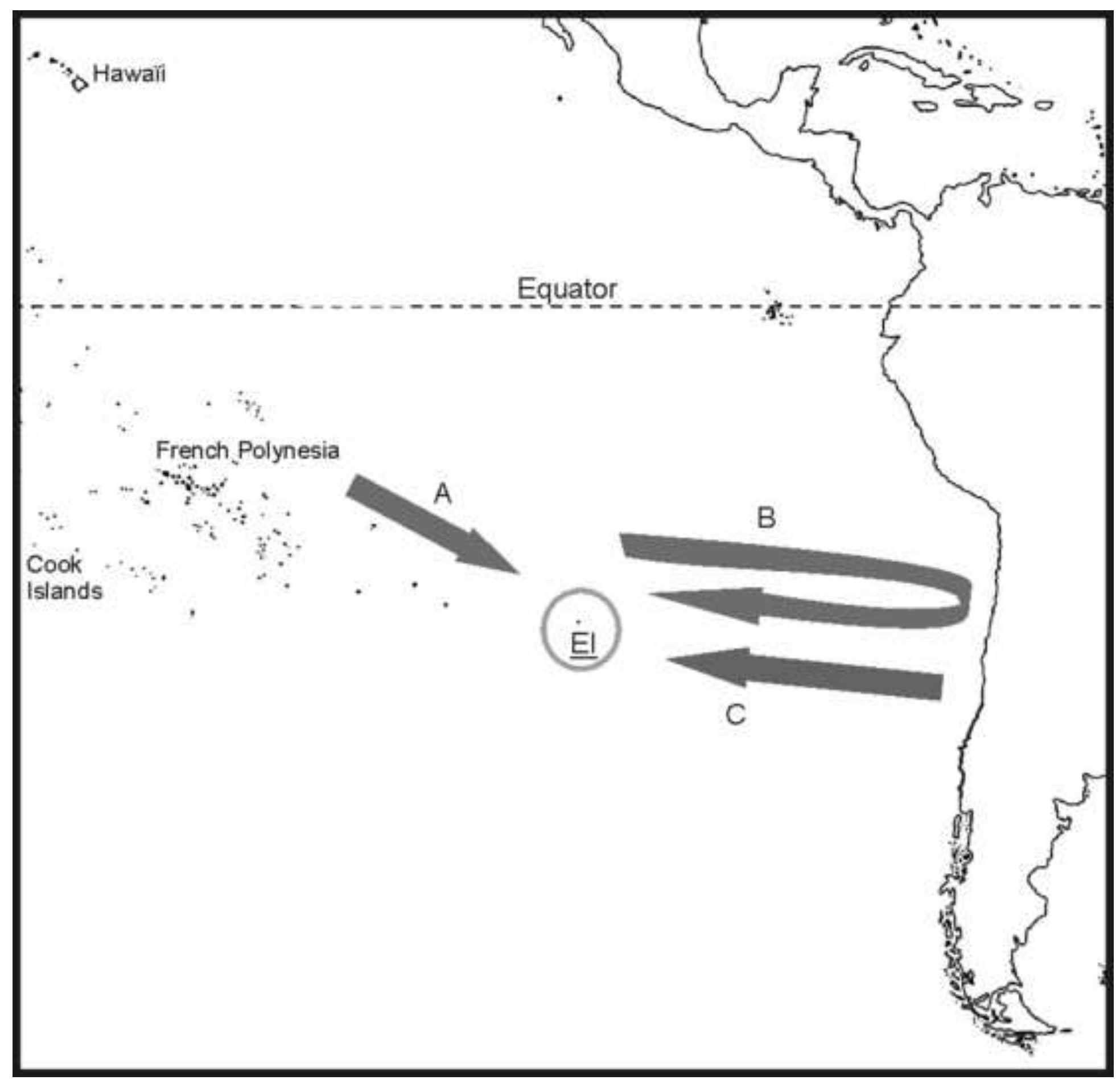



Appendix_1
Click here to download Supplementary Data: APPENDIX_1.doc

Click here to download Supplementary Data: APPENDIX_1.doc

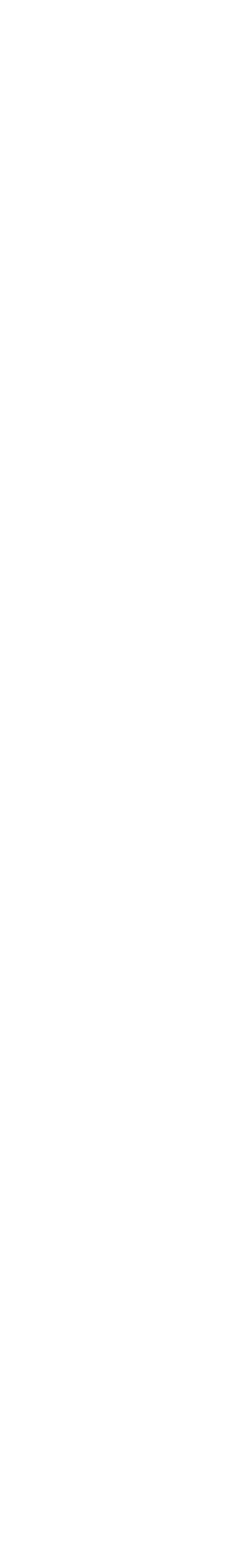

